\title{
A REAPPRAISAL OF SANTA FE: RULE 10b-5 AND THE NEW FEDERALISM
}

\author{
Ralph C. Ferrara † and Marc I. Steinberg †
}

\section{INTRODUCTION}

Almost four years ago, in Santa Fe Industries, Inc. v. Green, ${ }^{1}$ the Supreme Court refused to recognize an actionable claim under section 10(b) of the Securities Exchange Act of $1934^{2}$ and rule 10b-5 thereunder ${ }^{3}$ for alleged breaches of fiduciary duty in connection

t General Counsel, Securities and Exchange Commission. B.S.B.A. 1967, Georgetown University; J.D. 1970, University of Cincinnati; LL.M. 1972, National Law Center, George Washington University.

If Special Counsel, Office of the General Counsel, Securities and Exchange Commission. Adjunct Professor, Georgetown University Law Center. A.B. 1972, University of Michigan; J.D. 1975, University of California, Los Angeles; LL.M. 1977, Yale University.

The authors extend their appreciation and thanks to Bernard Wexler for laying the groundwork for this article.

The Securities and Exchange Commission, as a matter of policy, disclaims responsibility for any private publication by any of its employees. The views expressed herein are those of the authors and do not necessarily reflect the views of the Commission or of the authors' colleagues on the staff of the Commission.

1430 U.S. 462 (1977).

215 U.S.C. $\$ 78 j(b)$ (1976). Section 10(b) provides:

Section 10. It shall be unlawful for any person, directly or indirectly, by the use of any means or instrumentality of interstate commerce or of the mails, or of any facility of any national securities exchange-

(b) To use or employ, in connection with the purchase or sale of any security registered on a national securities exchange or any security not so registered, any manipulative or deceptive device or contrivance in contravention of such rules and regulations as the Commission may prescribe as necessary or appropriate in the public interest or for the protection of investors.

317 C.F.R. $\$ 240.10 b-5$ (1979). Rule $10 \mathrm{~b}-5$ provides:

It shall be unlawful for any person, directly or indirectly, by the use of any means or instrumentality of interstate commerce, or of the mails, or of any facility of any national securities exchange,

(1) to employ any device, scheme, or artifice to defraud,

(2) to make any untrue statement of a material fact or to omit to state a material fact necessary in order to make the statements made, in the light of the circumstances under which they were made, not misleading, or

(3) to engage in any act, practice, or course of business which operates or would operate as a fraud or deceit upon any person, in connection with the purchase or sale of any security. 
with a corporate merger. ${ }^{4}$ The Santa Fe Court concluded that, absent "manipulation" or "deception," the statute and rule do not reach breaches of fiduciary duty. ${ }^{5}$ The Supreme Court's decision was widely regarded as sharply curtailing the scope of rule $10 \mathrm{~b}-5 .^{6}$ In what has become an important caveat to the Santa $F e$ holding, however, the Court reasoned in footnote fourteen:

[The plaintiffs'] major contention in this respect is that the majority stockholder's failure to give the minority advance notice of the merger was a material nondisclosure, even though the Delaware short-form merger statute does not require such notice. But respondents do not indicate how they might have acted differently had they had prior notice of the merger. Indeed, they accept the conclusion of both courts below that under Delaware law they could not have enjoined the merger because an appraisal proceeding is their sole remedy in the Delaware courts for any alleged unfairness in the terms of the merger. Thus, the failure to give advance notice was not a material nondisclosure within the meaning of the statute or the Rule. ${ }^{7}$

Today, however, no plaintiff would concede that appraisal is his sole remedy under Delaware law in a Santa Fe-type situation. Shortly after Santa Fe, the Delaware Supreme Court reexamined its traditional merger doctrines and adopted a new approach to the subject. ${ }^{8}$ This approach has proved significantly more sensitive than prior state law to the interests of minority shareholders. ${ }^{9}$ Concomitantly, federal courts have contributed to the protection of investor interests: noting that shareholders may bring state law claims based on breaches of fiduciary duty, a number of federal

4430 U.S. at 471 . In Santa Fe, minority shareholders objected to the terms of a short-form merger pursuant to a Delaware state statute. In lieu of pursuing their appraisal remedies, the shareholders commenced an action on behalf of the corporation and other minority shareholders seeking to set aside the merger or to recover the alleged full value of their shares. Id. 466-67.

$5 \mathrm{Id}$. 473-74.

6 E.g., Campbell, Santa Fe Industries, Inc. v. Green: An Analysis Two Years Later, 30 Manne L. Rev. 187 (1979); Jacobs, Rule 10b-5 and Self Dealing by Corporate Fiduciaries: An Analysis, 48 U. Civ. L. Rev. 643 (1979); Ratmer, "Federal Corporation Law" Before and After Santa Fe Industries v. Green, in Ninth ANNual Institute on Securdties Regulation-Corporate Transcrimt SERrEs 305, 322 (Fleischer, Lipton, \& Vandegrift eds. 1978); Note, Suits for Breach of Fiduciary Duty Under Rule 10b-5 After Santa Fe Industries, Inc. v. Green, 91 HaRv. L. Rev. 1874 (1978).

$\tau 430$ U.S. at 474 n.14 (citations omitted).

8 See, e.g., Roland Int'l Corp. v. Najjar, 407 A.2d 1032 (Del. 1979); Tanzer v. International Gen. Indus., Inc., 379 A.2d 1121 (Del. 1977); Singer v. Magnavox Co., 380 A.2d 969 (Del. 1977).

9 See notes 85-90 infra and text accompanying notes 75-90 infra. 
courts have concluded that, in certain circumstances, the nondisclosure of facts needed in order to bring such claims constitutes "deception" within the meaning of section $10(\mathrm{~b})$ and rule $10 \mathrm{~b}-5 .{ }^{10}$

The evolution of Santa $F e$ and its progeny in the federal and state courts can be seen as an experiment in American federalism. ${ }^{11}$ Prior to Santa Fe, it was widely felt that state corporation laws inadequately protected shareholders from overreaching by management. Indeed, the trend towards "flexible" and "modern" corporation statutes was frequently characterized as a "race to the bottom" that ignored all interests except management's. ${ }^{12}$ The remedies proposed for the perceived abuses were often some form of federal regulation. A number of commentators urged a system of federal chartering of corporations, ${ }^{13}$ while others advocated statutory adoption of federal standards of corporate responsibility ${ }^{14}$ or an expan-

10 See, e.g., Healey v. Catalyst Recovery, Inc., 616 F.2d 641 (3d Cir. 1980); Alabama Farm Bureau Mut. Cas. Co. v. Alabama Fidelity Life Ins. Co., 606 F.2d 602 (5th Cir. 1979), cert. denied, 101 S. Ct. 77 (1980); Kidwell ex rel. Penfold v. Meikle, 597 F.2d 1273 (9th Cir. 1979); Goldberg v. Meridor, 567 F.2d 209 (2d Cir. 1977), cert. denied, 434 U.S. 1069 (1978); Wright v. Heizer Corp., 560 F.2d 236 (7th Cir. 1977), cert. denied, 434 U.S. 1066 (1978). See also Pellman v. Cinerama, Inc., No. 78-4508 (S.D.N.Y. Nov. 7, 1980); Merritt v. Colonial Foods, Inc., [Current] FED. SEc. L. ReP. (CCH) $\llbracket 97,689$.

11 It is important to emphasize that the term "federalism" is used in this Article in a colloquial sense only, without implicating constitutional overtones. Speaking in terms of constitutional federalism in the context of the constitutionality of the Illinois Business Take-Over Act, IrL. REv. STAT. ch. I21\%, $\$ 137.51$ et seq. (1979), the Seventh Circuit's approach is analogous to the issues addressed in this Article:

The possibility-and perhaps probability-that different levels of government will take quite dissimilar approaches to similar problems is inherent in federalism. But these divergencies are not necessarily dysfunctional; the states in our system have long served as laboratories of social experiment-free, within limits, to evolve strategies of their own to meet pressing problems.

MITE Corp. v. Dixon, [Current] FEed. SEc. L. Rep. (CCH) $\pi 97,660$, at 98,494 (7th Cir. Oct. 17, 1980).

12 E.g., Cary, Federalism and Corporate Law: Reflections Upon Delaware, 83 YALE L.J. 663 (1974); Folk, Corporation Statutes: 1959-1966, 1966 DukE L.J. 875; Jennings, Federalization of Corporation Law: Part Way or All the Way, 31 Bus. LAw. 991 (1976); Kaplan, Fiduciary Responsibility in the Management of the Corporation, 31 Bus. LAw. 883 (1976); Schwartz, Federal Chartering of Corporations: An Introduction, 61 GEo. L.J. 71 (1972); Note, Federal Chartering of Corporations: A Proposal, 61 GEo. L.J. 89 (1972).

13 E.g., R. Nader, The Case for Federal Chartering, in Corporate Power IN AnIERrCA 67 (R. Nader \& M. Green eds. 1973); Henning, Federal Corporate Chartering for Big Business: An Idea Whose Time has Come?, 21 DePaul L. Rev. 915 (1972); Reuschlein, Federalization-Design for Corporate Reform in a National Economy, 91 U. PA. L. Rev. 91 (1942); Schwartz, supra note 12; Note, supra note 12; Note, Federal Chartering of Corporations: Constitutional Challenges, 61 GEO. L.J. 123 (1972); Comment, Law for Sale: A Study of the Delaware Corporation Law of 1967, 117 U. PA. L. Rev. 861, 898 (1969).

14 E.g., Cary, supra note 12; Ruder, Pitfalls in the Development of a Federal Law of Corporations by Implication Through Rule 10b-5, 59 Nw. U.L. Rev. 185 (1964); Vagts, The Governance of the Corporation: The Options Available and the Power to Prescribe, 31 Bus. LAw. 929 (1976). 
sion of existing federal securities law remedies. ${ }^{15}$ Indeed, federal regulation of various aspects of corporation law became increasingly common. Both courts ${ }^{16}$ and commentators ${ }^{17}$ spoke of an emerging "federal corporation law." Interestingly, after Santa $F e$, the roles have been somewhat reversed, particularly in the Delaware courts. ${ }^{18}$ Generally, it is now the state courts that scrutinize alleged breaches of fiduciary duty while the lower federal courts apply footnote fourteen of Santa $\mathrm{Fe}$ to extend federal protection to shareholders in such cases. ${ }^{19}$

This Article shall examine Santa $F e$ and its progeny from the preceding perspective. First, for historical purposes, it will describe

15 E.g., Fleischer, "Federal Corporation Law": An Assessment, 78 HaRv. L. Rev. 1146 (1965); Folk, Corporation Law Developments-1969, 56 VA. L. Rev. 755 (1970). Cf. Kaplan, supra note 12 (discussing possibilities for expansion of rule 10b-5); Jennings, supra note 12 (discussing recent expansion of rule 10b-5).

16 E.g., McClure v. Borne Chem. Co., 292 F.2d 824 (3d Cir.), cert. denied, 368 U.S. 939 (1961).

17 Fleischer, supra note 15; Friendly, In Praise of Erie-And of the New Federal Common Law, 39 N.Y.U.L. Rev. 383, 413-14.

18 See note 8 supra \& accompanying text.

19 See note 10 supra \& accompanying text.

There appears to be little question that recent Supreme Court decisions have restricted the reach, scope and effect of the federal securities laws. See, e.g., Aaron v. SEC, $100 \mathrm{~S}$. Ct. 1945 (1980) (scienter required in SEC injunctive actions under $\S 10(b)$ of Securities Exchange Act, rule 10b-5 thereunder, and $\$ 17(\mathrm{a})(1)$ of Securities Act); Chiarella v. United States, $100 \mathrm{~S}$. Ct. 1108 (1980) (no duty to disclose under $\$ 10(\mathrm{~b})$ of Securities Exchange Act arises from mere possession of nonpublic market information); Transamerica Mortgage Advisers, Inc., v. Lewis, 444 U.S. 11 (1979) (no implied private right of action under $\$ 206$ of the Investment Advisers Act; limited implied private right of action under $\$ 215$ ); Touche Ross \& Co. v. Redington, 442 U.S. 560 (1979) (no implied private right of action under $\S 17(a)$ of the Exchange Act); International Bhd. of Teamsters v. Daniel, 439 U.S. 551 (1979) (interest in noncontributory, compulsory pension plan not "security" subject to regulation under Securities Acts); SEC v. Sloan, 436 U.S. 103 (1978) (limiting SEC's right to suspend summarily for successive 10-day periods trading in registered securities); Santa Fe Indus., Inc. v. Green, 430 U.S. 462 ( 1977 ) (breach of fiduciary duty, without manipulation or deception, not actionable under $\$ 10(\mathrm{~b})$ of Exchange Act and rule 10b-5); Piper v. Chris-Craft Indus., Inc., 430 U.S. 1 (1977) (defeated tender offeror has no standing to bring implied private right of action for damages under $\$ 14(\mathrm{e})$ of Exchange Act); Ernst \& Ernst v. Hochfelder, 425 U.S. 185 (1976) (scienter required in private damage actions under $\S 10(b)$ and rule 10b-5); Blue Chip Stamps v. Manor Drug Store, 421 U.S. 723 (1975) (only purchasers and sellers have standing to bring implied private cause of action for damages under $\$ 10(\mathrm{~b})$ and rule 10b-5). This trend is particularly evident when the recent cases are contrasted with expansive decisions of the past. See, e.g., Superintendent of Ins. v. Bankers Life \& Cas. Co., 404 U.S. 6 (1971). See generally Lowenfels, Recent Supreme Court Decisions Under the Federal Securities Laws: The Pendulum Swings, 65 Geo. L.J. 891 (1977); Steinberg, Implied Private Rights of Action Under Federal Law, 55 Notre DAine LAw. 33 (1979). With respect to $\$ 10(\mathrm{~b})$, Justice Blackmun, dissenting in Chiarella, stated: "The Court continues to pursue a course, charted in certain recent decisions, designed to transform $\S 10$ (b) from an intentionally elastic 'catchall' provision to one that catches relatively little of the misbehavior that all too often makes 
the chartering states' "race for the bottom" in the pre-Santa $F e$ period. Second, the Article will turn to the Santa Fe line of cases in both the federal and state courts. As hopefully will be seen, the respective positions taken by the federal and state tribunals represent a surprising and delicate experiment in federalism.

\section{II. "The Race for the Bottom"-A Brief Overview}

Shortly after the passage of the Delaware Corporation Law of 1967,20 a critical commentator observed:

The sovereign state of Delaware is in the business of selling its corporation law. This is profitable business, for corporation law is a good commodity to sell. The market is large, and relatively few producers compete on a national

investment in securities a needlessly risky business for the uninitiated investor." $100 \mathrm{~S}$. C. at 1123-24 (Blackmun, J., dissenting).

On some specific issues, however, the Court has departed from this restrictive approach. See, e.g., Aaron v. SEC, 100 S. Ct. 1945 (1980) (scienter not required in SEC injunctive actions under $\$ 17(\mathrm{a})(2)$ \& (3) of Securities Act); United States v. Naftalin, 441 U.S. 768 (1979) (reach of $\$ 17(a)$ of Securities Act extends beyond actual purchasers and sellers and encompasses aftermarket trading frauds).

If the Supreme Court ultimately rejects the imposition of liability under $\$ 10$ (b) and rule $10 \mathrm{~b}-5$ in cases relying on footnote fourteen of Santa $F e$, a possible remedy under the federal securities laws for alleged violations of this sort may be $\S 17$ (a) of the Securities Act. In light of recent Supreme Court decisions, plaintiffs may be forced to argue under that section that a private right of action exists, that aggrieved offerees have standing, and that there is no scienter requirement. After Aaron, it is clear that the SEC is not required to prove scienter in Commission injunctive actions based on violations of $\$ 17(\mathrm{a})(2) \&(3)$. 100 S. Ct. at 1956-57. For scholarly comment on $\$ 17(\mathrm{a})$, see e.g., Hazen, $A$ Look Beyond the Pruning of Rule 10b-5: Implied Remedies and Section 17(a) of the Securities Act of 1933, 64 VA. L. Rev. 641 (1978); Horton, Section 17(a) of the 1933 Securities Act-The Wrong Place for a Private Right, $68 \mathrm{Nw}$. U.L. Rev. 44 (1973); Steinberg, Section 17(a) of the Securities Act of 1933 After Naftalin and Redington, 68 GEo. L.J. 163 (1979).

Another possible remedy in Santa $F e$ footnote fourteen-type cases is $\$ 14(a)$ of the Securities Exchange Act and rule 14a-9 promulgated thereunder. Organic corporate changes, such as mergers or consolidations, require a shareholder vote, and hence, solicitation of proxies. In these types of situations, shareholders may be able to seek relief under both $\S 10(\mathrm{~b})$ and $\S 14(\mathrm{a})$. Because the standards underlying a $\S 14(a) / 14 a-9$ remedy may differ from those in a $\$ 10(b) / 10 b-5$ cause of action, the implied remedy under $\$ 14(\mathrm{a})$ may sometimes give relief where the $\$ 10$ (b) remedy may fail. Moreover, because mergers may involve the Santa Fetype situation, in which dissenting shareholders are frozen out, actions brought pursuant to $\S 14(a)$ will bring the Santa $F e$ state law analysis into sharp focus. Indeed, the federal-state tension that underlies much of Santa $F e$ may attach to any proxy-related claim in which the minority does not receive fair share for its stock. In contrast to Santa Fe, however, the proxy provisions do not contain a requirement of "manipulative" or "deceptive" conduct. Thus, $\$ 14$ (a) may arguably be used to avoid the strictures of Santa Fe. See Hazen, Corporate Mismanagement in the Federal Securities Act's Anti-Fraud Provisions: A Familiar Path With Some New Detours, 20 B.C.L. Rev. 819, 850 (1979).

20 Dex. Cone AnN. tit. 8, $\$ \$ 101-398$ (1974 \& Supps. $1978 \& 1979$ ). 
scale. The consumers of this commodity are corporations, and as we shall see, Delaware, like any other good businessman, tries to give the consumer what he wants. In fact, those who will buy the product are not only consulted about their preferences, but are also allowed to design the product and run the factory. ${ }^{21}$

Although this statement may appear somewhat exaggerated and unfair, a number of observers have found it reasonably accurate. ${ }^{23}$ For example, Professor William L. Cary, an eminent corporation law scholar and former Chairman of the Securities and Exchange Commission, described state corporation law as a "race for the bottom" that Delaware had won. ${ }^{23}$

Delaware, however, was not alone in enacting a corporation law designed to encourage corporate chartering in the state. New Jersey, for example, eager for the revenues derived from corporate chartering, enacted in 1896 what has been viewed as the first of the modern liberal corporation statutes. ${ }^{24}$ The Act attracted the incorporation of the New Jersey trusts, including the old Standard Oil Company. ${ }^{25}$ At the insistence of then Governor Woodrow Wilson, New Jersey eventually tightened its corporation law in $1913,{ }^{26}$ but the tone of

21 Comment, supra note 13, at 861-62.

22 See, e.g., authorities cited in note 12 supra. Professor Manning has characterized state corporation statutes as "towering skyscrapers of rusted girders, internally welded together and containing nothing but wind." Manning, supra note 12, at 245 n.37. Another distinguished scholar, Professor Folk, who served as reporter to the Delaware Corporation Law Revision Committee, has said of corporation law generally:

Almost without exception, the key movement in corporation law revisions is toward ever greater permissiveness ... Explicitly positing an objective of "flexibility," statutory revisers . . . have usually sought to enlarge the ambit of freedom of corporate management to take whatever action it may wish .... Indeed the new statutes seem to be exclusively concerned with only one constitutent of the corporate community-management-and have disregarded the interests of shareholders and creditors, let alone more tangentially interested parties, such as employees, customers, and the general public. ... [I]t appears that these trends are irreversible, absent some presently unforeseeable changes in the basic structure of the American economy. State efforts to go against such deepseated dispositions, even if desired, would be futile.

Folk, Some Reflections of a Corporation Law Draftsman, 42 ConN. B.J. 409, 410 (1968). See generally, Symposium on Federal and State Roles in Establishing Standards of Conduct for Corporate Management, 31 Bus. LAw. 856 (1976), in which the inadequacies of state corporation law were debated, discussed, and documented at great length (and in which Delaware and other prominent states had their ardent supporters).

23 Cary, supra note 12, at 705.

24 E. Dodd \& R. Baker, Cases and Materials on Conporations 38 (2d ed. 1951); Cary, supra note 12, at 664 .

25 Cary, supra note 12 , at 664 .

${ }^{26}$ Id. See also E. DoDd \& R. BAKER, supra note 24, at 38. 
permissiveness resurfaced in the state's Corporation Law Revision Commission's Report of 1968:

Since World War I, however, it is clear that the trend has been steadily toward Delaware incorporation as New Jersey has fallen further behind in modernizing its corporation act to meet current needs and practices. The Commission trusts that this trend will now be reversed, in light of the revision of the New Jersey corporation laws herewith submitted. ${ }^{27}$

Despite New Jersey's efforts, Delaware has emerged as the clear victor in this race. ${ }^{28}$ As Professor Cary points out, however, if Delaware had elected not to retain its lead, other states would have hastened to assume its lucrative position..$^{29}$

Due to this perverse competition, the adequacy of the protections that state corporation law provides investors has long been questioned. $^{30}$ As alluded to above, this competition rewards the state that can be most permissive. All too often the competition is sadly one-sided. Frequently, entrenched management's viewpoint is dominant in the state capitals, ${ }^{31}$ and little attention is given to traditional fiduciary standards or to the investor's claim to fair treatment. ${ }^{32}$

In response to this situation, many commentators have advocated the application of federal standards of corporate responsibility. ${ }^{33}$ Some observers believed that rule $10 \mathrm{~b}-5$ should have been expansively interpreted to act as the watchdog for all corporate

27 N.J. Stat. ANN. $\$ 14$ A, at $x$ (West 1968).

28 See Cary, supra note 12 , at 668 :

Delaware understandably does not wish to surrender its lead. Amending its law in 1969, and again in 1970 and 1971, it is setting the pace. It likes to be number one. With some justification Delaware corporate counsel take pride in their role and enjoy the fees that flow from it. The system "engenders a volume of business for the bar which tends to be regarded as a vested interest, so that any attempt to retrace steps would encounter opposition in powerful quarters." Most important, the raison d'etre behind the whole system has been achieved-revenue for the state of Delaware.

Id. (citations omitted).

29 Id. 665. Apparently, Nevada has attempted to become the western Delaware but has not had comparable success. Id. See also Comment, supra note 13, at 871-72.

30 See authorities cited in note 12 supra.

31 Cf. Cary, supra note 12, at 690-92 (discussing links between Delaware Law Revision Commission of 1967 and the corporate bar); Comment, supra note 13 (same).

32 Cary, supra note 14; Folk, supra note 22; Comment, supra note 13.

33 See authorities cited in notes 14 \& 15 supra. 
activity. ${ }^{34}$ Indeed, the impetus for this approach may have been provided by the federal judiciary itself. ${ }^{35}$ For example, the federal courts interpreted rule $10 \mathrm{~b}-5$ in various cases to protect purchasers and sellers from persons who improperly traded on the basis of inside information, ${ }^{36}$ to provide relief to participants in transactions involving misleading corporate publicity, ${ }^{37}$ and to dispense with the common-law reliance requirement in cases of nondisclosure. ${ }^{38}$

Expansion of rule 10b-5 to encompass the "corporate universe" was not the only method proposed by commentators to advance the application of federal standards of corporate responsibility. One alternative, federal incorporation, was far from novel. Indeed, from 1903 to 1914, no less than twenty bills were introduced in Congress to provide for the incorporation of companies conducting interstate business or to require such companies to obtain federal licenses. ${ }^{39}$ Although never successful, the concept continues to attract the attention of reformers. ${ }^{40}$

34 See authorities cited in note 15 supra.

35 McClure v. Borne Chem. Co., 292 F.2d 824, 834 (3d Cir.), cert. denied, 368 U.S. 939 (1961) (Securities Exchange Act termed "far reaching Federal substantive corporation law"). See also cases cited in notes 36-38 infra.

36 See, e.g., SEC v. Geon Indus., Inc., 531 F.2d 39 (2d Cir. 1976); SEC v. Shapiro, 494 F.2d 1301 (2d Cir. 1974); SEC v. Great Am. Indus., Inc., 407 F.2d 453, 462 (2d Cir. 1968) (Kaufman, J., concurring), cert. denied, 395 U.S. 920 (1969) ("[a]ny claim that material facts were withheld in a transaction in connection with the sale or purchase of securities must be scrutinized with care, whether or not there would have been liability at common law for such a deed."). But see Chiarella v. United States, $100 \mathrm{~S}$. Ct. 1108 (1980) (no duty to disclose under $\S 10$ (b) arises from mere possession of nonpublic market information). This prohibition against insider trading extends as well to tippees. See, e.g., SEC v. Geon Indus., Inc., 531 F.2d 39 (2d Cir. 1976).

37 See, e.g., SEC v. Texas Gulf Sulphur Co., 401 F.2d 833 (2d Cir. 1968) (en banc), cert. denied, 394 U.S. 976 (1969):

[A]nyone in possession of material inside information must either disclose it to the investing public, or, if he is disabled from disclosing it in order to protect a corporate confidence, or he chooses not to do so, must abstain from trading in or recommending the securities concerned while such inside information remains undisclosed.

Id. 848.

${ }^{38}$ See, e.g., Affiliated Ute Citizens v. United States, 406 U.S. 128 (1972). In another case, although there was no holding that reliance is unnecessary, the Court applied $\S 10(\mathrm{~b})$ where there was a somewhat tenuous connection between the securities transaction and the fraudulent activity. See Superintendent of Ins. v. Bankers Life \& Cas. Co., 404 U.S. 6 (1971).

39 Federal Trade Commission, Compilation of Proposals and Views For and Against Incorporation or Licensing of Corporations, S. Doc. No. 92, 70th Cong., Ist Sess., pt. 69-A, at 44 (1934) (quoted in Schwartz, supra note 12, at 71). Indeed, "[t]he advisability of such congressional charters was debated in the Constitutional Convention, and federal incorporation was recommended by Presidents Theodore Roosevelt, Taft, and Wilson." Reuschlein, supra note 13, at 106-07 (citations omitted).

40 See authorities cited in note 13 supra. 
A third alternative, proposed by Professor Cary, recommended the adoption of a federal statute that would provide for, inter alia, the implementation of federal fiduciary standards, a requirement that all "interested directors" transactions be fair, and greater shareholder participation in the corporate governance area. ${ }^{41}$ Recent bills introduced in Congress, somewhat resembling Professor Cary's concept, may be viewed as akin to proposals seeking a federal corporation law. One such bill, the "Corporation Democracy Act of $1980, " 42$ would apply to the country's 800 largest corporations and would address the composition and duties of boards of directors, the public disclosure of corporate operations and activities, the rights of employees, the impact of plant closings on affected communities, the regulation of interlocking directorates, and the accountability of corporate officers for violations of federal law by the corporate entity. ${ }^{43}$

The preceding discussion illustrates the considerable appeal of federal solutions to problems of corporation law. Ironically, however, several commentators have suggested that the chartering states' "race for the bottom" was, at least in part, a result of federal regu-

41 Cary, supra note 14, at 701-03. As outlined by Cary:

To illustrate, some of the major provisions of such a federal statute might include (1) federal fiduciary standards with respect to directors and officers and controlling shareholders; (2) an "interested directors" provision prescribing fairness as a prerequisite to any transaction; (3) a requirement of certain uniform provisions to be incorporated in the certificate of incorporation: for example, authority to amend by-laws, initiate corporate action, or draw up the agenda of shareholders' meetings shall not be vested exclusively in management; (4) a more frequent requirement of shareholder approval of corporate transactions, with limits placed upon the number of shares authorized at any one time; (5) abolition of nonvoting shares; (6) the scope of indemnification of directors specifically prescribed and made exclusive; (7) adoption of a long-arm provision comparable to $\S 27$ of the Securities Exchange Act to apply to all transactions within the corporate structure involving shareholders, directors and officers.

Id. 702 (citations omitted).

42 H.R. 7010, 96th Cong., 2d Sess. (1980).

43 Id. Another such bill, the "Protection of Shareholders' Rights Act of 1980," S. 2567, 96th Cong., 2d Sess. (1980), introduced by Senator Metzenbaum, has comparable provisions. See 550 Sec. REg. \& L. REP. (BNA) F-1 (April 23, 1980). Pertinent provisions of these bills, if enacted, would require that a majority of a corporation's board be composed of independent directors, that the audit and nominating committees be composed solely of independent directors, that each director owes a "duty of loyalty" and a "duty of care" to the corporation and its shareholders, that cumulative voting be used in directors' elections, that a shareholder vote be conducted on major corporate transactions, and that extensive disclosure be provided in regard to such matters as employment discrimination, compliance with environmental controls, tax rates, cost of legal and accounting fees, and planned plant closings. 
lation in the area of corporation law. ${ }^{44}$ One commentator has written:

In any event, all this federal legislation and activity has gone far to create the belief that the "bad" parts of the old corporate machinery have been pretty well replaced, to the further complacency of the draftsmen of state corporation laws, to which complacency is perhaps also added the uncomfortable suspicion that what they are doing is not so important anyhow. ${ }^{45}$

It may be an oversimplification to emphasize the causal relation between federal regulation and state permissiveness-numerous other considerations were important in the "race for the bottom." 46 Nonetheless, the development of a "federal corporation law" provided a plausible justification for state corporation laws and judicial decisions to discount the interests of investors and the public. For example, the New Jersey Corporation Law Revision Commission argued that "it is clear that the major protections to investors, creditors, employees, customers, and the general public have come, and must continue to come, from Federal legislation and not from state corporation acts. . . [ [T]he means of assuring such protections must be provided by the Federal Government." 47 The relationship between increasing federal regulation and state permissiveness was a curious one; as will be discussed below, its curiosity was heightened by some state courts' responses to the Supreme Court's decision in Santa Fe.

\section{Santa Fe Industries, Inc. v. Green-AN Overview}

Santa Fe Industries, Inc. $v$. Green ${ }^{48}$ involved the merger ${ }^{49}$ of the Kirby Lumber Corporation into its parent, Santa Fe Industries,

44 See, e.g., Latty, Why Are Business Corporation Laws Largely "Enabling"?, 50 Corinelx L.Q. 599 (1965); Sowards \& Mofsky, Factors Affecting the Development of Corporation Law, 23 Mrami L. Rev. 746 (1969) (quoting authorities); Comment, supra note 13, at 896. Cf. Folk, supra note 12 , at 958 ("Thus the overall balance is between increasing state law permissiveness and widening federal regulation-a development not without parallel in other areas of life and law.").

45 Latty, supra note 44 , at 617 .

46 See id. at $611-19$.

47 N.J. Stat. AnN. $\$ 14 A$, at xi (West 1968).

48430 U.S. 462 (1977).

49 The type of merger involved in Santa $F e$ is only one of a variety of ways that majority shareholders can squeeze out minority shareholders. Another, spawned by the depressed markets of recent years, is the "going private" transaction in which the controlling persons of a corporation eliminate public shareholders while retaining their control and ownership of the business. In 1979, the 
Inc., which owned ninety-five percent of Kirby's stock. Santa Fe availed itself of a simplified Delaware procedure known as a "short-

SEC adopted Rules $13 \mathrm{e}-3$ and $13 \mathrm{e}-4$ relating to going private transactions by public companies or their affiliates. See Securities Act Release Nos. 6100, 6109 (August 1979). In general, the rules prohibit fraudulent, deceptive, and manipulative acts or practices in connection with going private transactions and prescribe new filing, disclosure, and dissemination requirements as a means reasonably designed to prevent such acts or practices. Of particular interest, the original proposal for Rule 13e-3 included the requirement that a going private transaction must be both substantively and procedurally fair to unaffiliated security holders. Securities Exchange Act Release No. 14185 (Nov. 17, 1977). Many commentators expressed the view that the Commission should not attempt to regulate the fairness of going private transactions because such regulation was more properly within the province of the states. The Commission, in adopting Rule 13e-3 and Schedule 13E-3, required the issuer to state whether it reasonably believes that the going private transaction is fair or unfair to unaffliated security holders. While the Commission deferred its decision on the promulgation of a "federal fairness requirement" until it could review the efficacy of the Rule 13e-3 adopted, it nevertheless continued to adhere to the position that "the views expressed in the 1977 release are sound and therefore specifically affirms those views."

A second situation, similar to the going private scenario, is the "buy-out." In this transaction, a controlling group causes "its" corporation to sell its assets for cash, which is frequently then invested in tax-exempt securities. The members of the controlling group derive substantial benefits from this arrangement. The insiders, who are often in high tax brackets, are frequently motivated by tax avoidance considerations. The buy-out generally results in no realization of gain or loss for tax purposes, and thus allows insiders to defer their tax liabilities. Additionally, highly remunerative employment contracts are often involved. The SEC's Division of Corporation Finance has expressed concern that past disclosure in buy-out situations has not "adequately highlighted the actual and potential conflicts of interest presented to management or its affliates in transactions such as these, which are structured in part to accommodate their tax or estate needs and in which the purchaser also retains the management under long term employment arrangements." Securities Exchange Act Release No. 15572 (February 1979).

The public shareholder's assessment of the "buy-out" is quite different from that of the controlling group. The public shareholder receives no employment contract. Further, the switch from taxable dividends to tax-exemption may frustrate his expectations. Indeed, had he wanted a tax-exempt investment, rather than an investment in " a going business that offered a prospect of increased income and capital appreciation, he no doubt would have purchased tax-exempt securities in the first place. Thus, in a buy-out situation, the public shareholder is confronted with a choice between an interest in a new investment company or cash for his stock at a price somewhat above its market price. Perhaps largely for this reason, the SEC staff has taken the position that adequate disclosure must be made regarding, inter alia, the reasons for and the effect of the contemplated "buy-out" transaction, the terms of financing, the fairness of the price offered, and the rights of stockholders under state law. See Securities Exchange Act Release No. 15572.

It should be added that frequently the entity that buys the business does so with borrowed money-hence the term "leveraged buy-out." An investor caught in such a transaction may well question the fairness of being divested of his interest and foreclosed from any further participation in an enterprise that sophisticated investment bankers find attractive enough to warrant both heavy borrowing at today's high interest rates and agreement to onerous employment contracts with the controlling group. The SEC has initiated administrative actions in response to certain leveraged buy-out transactions. See In re Spartek Inc., Securities Exchange Act Release No. 15567, FED. SEc. L. Rep. (CCH) \ 81,961 (Feb. 14, 1979); In re Woods Corp., Securities Exchange Act Release No. 15337 (Nov. $16,1978)$. 
form" merger, under which a parent that owns at least ninety percent of a subsidiary's outstanding stock can absorb the subsidiary without being required to obtain approval by the shareholders of either corporation. ${ }^{50}$ The day after the merger became effective, Kirby's minority shareholders were informed that they would receive $\$ 150$ in cash for each of their shares, and that, if dissatisfied, they could seek appraisal ${ }^{51}$ in the Delaware courts. ${ }^{52}$

Santa $\mathrm{Fe}$ also provided the Kirby shareholders with an information statement containing facts and figures that convinced S. William Green, one of the recipients, that Kirby stock was actually worth at least $\$ 772$ a share.53 Green did not claim that these materials were deceptive. Indeed, he built his case on them. ${ }^{54}$ Green's basic premise was that the gross undervaluation of his shares was itself a "fraud" within the meaning of rule $10 \mathrm{~b}-5 .{ }^{.55}$

The district court found Green's argument unpersuasive. ${ }^{56}$ A majority of the Second Circuit, however, accepted it. The prevailing opinion held:

Whether full disclosure has been made is not the crucial inquiry since it is the merger and the undervaluation which constitute the fraud, and not whether or not the majority determines to lay bare their real motives. If there is no valid corporate purpose for the merger, then even the most brazen disclosure of that fact to the minority shareholders in no way mitigates the fraudulent conduct. ${ }^{57}$

The Supreme Court reversed. Citing a commentator's observation that Santa Fe and the Second Circuit's decision in a contemporaneous going private case ${ }^{58}$ were the first appellate decisions

50 Del. Code Ann. tit. 8, $\$ 253$ (1974).

51 The inadequacy of an exclusive appraisal right has been forcefully demonstrated elsewhere. E.g., Brudney \& Chirelstein, Fair Shares in Corporate Mergers and Takeovers, 88 HARv. L. REv. 297, 307 (1974) ("[Appraisal] neither serves nor is designed to serve as a remedy for the fiduciary misbehavior at which the fairness challenge is directed."); Manning, The Shareholder's Appraisal Remedy: An Essay for Frank Coker, 72 YArE L.J. 223 (1962).

52430 U.S. at 466.

$53 \mathrm{Id}$. 466-67.

54 Id. 474.

55 Green v. Santa Fe Indus., Inc., 533 F.2d 1283, 1285 (2d Cir. 1976).

56 Green v. Santa Fe Indus., Inc., 391 F. Supp. 849 (S.D.N.Y. 1975).

57533 F.2d 1283, 1292 (2d Cir. 1976).

58 Marshel v. AFW Fabric Corp., 533 F.2d 1277 (2d Cir.), vacated and remanded for a determination of mootness, 429 U.S. 881 (1976), dismissed, [19771978 Transfer Binder] FED. SEC. L. REP. (CCH) 『96,243 (S.D.N.Y. 1977). In Marshel, the Second Circuit held that

when controlling stockholders and directors of a publicly-held corporation cause it to expend corporate funds to force elimination of minority stock- 
to permit "a 10b-5 claim without some element of misrepresentation or nondisclosure," 59 the Court held "that the transaction . . . was neither deceptive nor manipulative and therefore did not violate either $\S 10(\mathrm{~b})$ of the [Exchange] Act or Rule 10b-5." 60

The plaintiffs also argued that a material nondisclosure had occurred because they had not received the information regarding the merger until after it had been consummated. The Court brushed this "timing" argument aside in what has become, due to lower court application, ${ }^{61}$ a most significant footnote. ${ }^{62}$

Santa $F e$ was scarcely a surprise after the Court's previous decisions in Ernst of Ernst v. Hochfelder ${ }^{63}$ and Cort v. Ash ${ }^{64}$ Hochfelder held that there can be no implied private right of action for damages under section $10(\mathrm{~b})$ and rule $10 \mathrm{~b}-5$, absent an allegation of scienter. ${ }^{65}$ The decision was predicated on a strict construction of rule $10 \mathrm{~b}-5$ and its statutory source, section $10(\mathrm{~b}){ }^{66}$ This approach to the language of the statute and rule was expressly affirmed and adopted by the Santa Fe court. ${ }^{87}$ In Cort, the Court demonstrated its reluctance to imply federal causes of action in areas traditionally left to state law. ${ }^{68}$ The Court observed that "corpora-

holders' equity participation for reasons not benefiting the corporation but rather serving only the interest of the controlling stockholders such Id. 1281.

conduct will be enjoined pursuant to Section $10(\mathrm{~b})$ and Rule 10b-5.

5989 HaRv. L. REv. 1917, 1926 (1976), quoted in Santa Fe, 430 U.S. at 475-76 n.15.

60430 U.S. at 474.

61 See note 10 supra \& accompanying text.

62430 U.S. at 474 n.14. See notes 76-97 infra \& accompanying text. For the language of footnote 14, see text accompanying note 6 supra.

63425 U.S. 185 (1976).

64422 U.S. 66 (1975).

65425 U.S. at 214.

${ }^{66}$ Id. 197, 200. Similarly, the Court has recently noted that its conclusion in

Hochfelder rested on several grounds, the "most important" of which was

the plain meaning of the language of $\$ 10(\mathrm{~b})$. It was the view of the

Court that the terms "manipulative," "device," and "contrivance"whether given their commonly accepted meaning or read as terms of art -quite clearly evinced a congressional intent to proscribe only "knowing or intentional misconduct." This meaning, in fact, was thought to be so unambiguous as to suggest that "further inquiry may be unnecessary."

Aaron v. SEC, 100 S. Ct. 1945, 1952 (1980) (citation omitted).

67430 U.S. at 472 .

68422 U.S. at 80 . The Court enunciated a four-prong test for determining the existence of an implied private right of action under a federal statute:

First, is the plaintiff "one of the class for whose especial benefit the statute was enacted," .... Second, is there any indication of legislative intent, explicit or implicit, either to create such a remedy or to deny one? Third, is it consistent with the underlying purposes of the legislative scheme to imply such a remedy for the plaintiff? And finally, is the cause 
tions are creatures of state law, and investors commit their funds to corporate directors on the understanding that, except where federal law expressly requires certain responsibilities of directors with respect to stockholders, state law will govern the internal affairs of the corporation." 69 Both cases evidence the Court's recent contraction of the scope of the federal securities laws. ${ }^{70}$ According to one commentator, Hochfelder, taken with Cort, "unequivocally reverses the trend toward expanding plaintiff's rights under the federal securities law." 71 Santa Fe combined the approaches of Hochfelder and Cort, employing a narrow approach to construction and stressing that the regulation of the internal management of corporations is within the ambit of state corporation law.

Santa $F e$ is undeniably significant. Had the Court upheld the Second Circuit's "new fraud" or "equitable fraud" concept, ${ }^{72}$ minority shareholders would have obtained the federal shield of protection from overreaching that many have argued they need. ${ }^{73}$ Justice White acknowledged this concern at the close of his majority opinion in Santa Fe: "There may well be a need for uniform federal fiduciary standards to govern mergers such as that challenged in this complaint. But those standards should not be supplied by judicial extension of $\S 10(\mathrm{~b})$ and Rule $10 \mathrm{~b}-5$ to 'cover the corporate universe." " 74

of action one traditionally relegated to state law, in an area basically the concern of the States, so that it would be inappropriate to infer a cause of action based solely on federal law?

Id. 78 (citations omitted) (emphasis in original). Recently, the Court evidently modified the four-prong Cort test. Under the new standard, the primary, if not controlling, criterion appears to be whether Congress intended, either expressly or by implication, to create a private remedy. See, e.g., Transamerica Mortgage Advisors, Inc. v. Lewis, 444 U.S. 11 (1979); Touche Ross \& Co. v. Redington, 442 U.S. 560 (1979); Cannon v. University of Chicago, 441 U.S. 677 (1979) (Powell, $\mathrm{J}$., dissenting) ("[T]he 'four factor' analysis of [Cort] is an open invitation to federal courts to legislate causes of action not authorized by Congress. It is an analysis not faithful to constitutional principles and should be rejected . . . ."). See generally Steinberg, Implied Private Rights of Action Under Federal Law, 55 Notre DAME Law. 33 (1979).

69422 U.S. at 84, quoted in Santa Fe, 430 U.S. at 479 (emphasis in Santa $F e$ ). See also Burks v. Lasker, 441 U.S. 47I, 478 (1979) ("As we have said in the past, the first place one must look to determine the powers of corporate directors is in the relevant State's corporation law").

70 See note 19 supra.

71 Lowenfels, supra note 19, at 900.

72 The Second Circuit, followed by a number of other federal courts, permitted rule $10 \mathrm{~b}-5$ actions even in situations not involving deception. Under the"new fraud" approach, rule 10b-5 liability could be premised on a wide range of corporate mismanagement. See generally Jacobs, supra note 6, at 57-61.

73 See note 12 supra.

74430 U.S. at 479-80 (footnotes omitted). Referring to Professor Cary's article, Mr. Justice White commented: "Professor Cary argues vigorously for com- 
Santa $\mathrm{Fe}$ makes it clear that a federal claim cannot be stated under rule 10b-5 without alleging a material deception. Although theoretically available, "manipulation" will probably be seldom used, because the Court seems inclined to read that word as a term of art referring to market operations. That construction is of doubtful relevance to the juggling of a corporation's assets and properties. ${ }^{75}$

As noted at the outset of this Article, however, Santa Fe had a second aspect, arising from the Court's comment that failure to provide the minority with advance notice was not a material nondisclosure because, as the plaintiffs conceded, "under Delaware law [the plaintiffs] could not have enjoined the merger because an appraisal proceeding [was] their sole remedy in the Delaware courts for any alleged unfairness in the terms of the merger." 76 Today no plaintiff would make this concession in a Santa $F e$ situation. Six months after Santa $\mathrm{Fe}$, in Singer v. Magnavox Co., ${ }^{77}$ the Delaware Supreme Court took a fresh look at its merger doctrines and embarked on a new course.

\section{Post-Santa Fe Decisions in the State Courts}

Perhaps influenced by the Supreme Court's decision in Santa $F e$, and the consequent likelihood of reduced federal regulation in the area of management malfeasance, ${ }^{78}$ the Delaware Supreme Court apparently has assumed this protective role. ${ }^{79}$ In Singer, ${ }^{80}$ minority shareholders frozen out by a merger sought nullification of the

prehensive federal fiduciary standards, but urges a 'frontal' attack by a new federal statute rather than an extension of Rule 10b-5." Id. 480 n.17.

75 See Hochfelder, 425 U.S. at 199 ("["Manipulative'] connotes . . . controlling or artificially affecting the price of securities."). This passage was cited with approval by the Santa $F e$ Court, which suggested that the word "manipulative" in the Exchange Act was used "in this technical sense of artificially affecting market activity." 430 U.S. at 477 . The Court also expressed the view that Congress would not 'have chosen this 'term of art' if it had meant to bring within the scope of $\$ 10$ (b) instances of corporate mismanagement, such as this, in which the essence of the complaint is that shareholders were treated unfairly by a fiduciary." Id. See also Aaron v. SEC, 100 S. Ct. 1945, 1952-55 (1980); Falls v. Fickling, 621 F.2d 1362 (5th Cir. 1980).

76430 U.S. at 474 n.14. Interestingly, prior to Santa $F e$, there was some authority that, under relevant state law, minority shareholders could not be eliminated in a cash-out merger transaction unless a valid business purpose could be shown. See, e.g., Bryan v. Brock \& Blevins Co., Inc., 490 F.2d 563, 571 (5th Cir.), cert. denied, 419 U.S. 844 (1974) (interpreting Georgia law).

77380 A.2d 969 (Del. 1977).

78 See notes $41-47$ supra \& accompanying text.

79 It is noteworthy that the Singer court viewed Santa $F e$ as a "current confirmation by the Supreme Court of the responsibility of a state to govern the internal affairs of corporate life." 380 A.2d at 976 n.6.

80 Singer v. Magnavox, 380 A.2d 969 (Del. 1977). 
merger and compensatory damages. The plaintiffs alleged that the sole purpose of the merger was removal of the minority, and that the majority had offered grossly inadequate compensation for stock held by the minority. ${ }^{81}$ In reversing the lower court's dismissal of the complaint on the ground that appraisal was the exclusive remedy, ${ }^{82}$ the Delaware high court stated that "a $\$ 251$ merger, made for the sole purpose of freezing out minority stockholders, is an abuse of the corporate process; and . . . states a cause of action for violation of a fiduciary duty." 83 Moreover, the court emphasized that even the existence of a valid business purpose would not preclude relief to the minority shareholders:

On the contrary, the fiduciary obligation of the majority to the minority stockholders remains and proof of a purpose, other than such freeze-out, without more, will not necessarily discharge it. In such case the Court will scrutinize the circumstances for compliance with the Sterling rule of "entire fairness" and, if it finds a violation thereof, will grant such relief as equity may require. ${ }^{84}$

Hence, under Singer, if it is alleged that the purpose of the merger is improper, the majority shareholders must prove a proper business purpose. Further, even if there is proof of a proper business purpose, a court must scrutinize the transaction for its entire fairness and award appropriate relief if a violation is found.

Singer was the harbinger of a new era in Delaware. Subsequent Delaware cases have confirmed and extended the viability of Singer's principles. From these decisions, a number of general principles can be proffered: a majority shareholder's fiduciary duty is not fulfilled simply by relegating the minority stockholders to their statu-

81 Id. 972.

82 Singer v. Magnovox [sic] Co., 367 A.2d 1349 (Del. Ch. 1976). A number of commentators have addressed the inadequacy of the appraisal remedy. See note 51 supra.

83380 A.2d at 980.

$84 \mathrm{Id}$. (emphasis added). In so holding, the court relied on the Sterling rule, Sterling v. Mayflower Hotel Corp., 33 Del. Ch. 293, 298, 93 A.2d 107, 110 (1952), that the majority must "bear the burden of establishing [the transaction's] entire fairness ... [which must] pass the test of careful scrutiny by the courts." See Singer, 380 A.2d at 976.

For further discussion of Singer, see, e.g., Brudney \& Chirelstein, A Restatement of Corporate Freezeouts, 87 YALE L.J. 1354 (1978); Elfin, Changing Standards and the Future Course of Freezeout Mergers, 5 J. Conp. Law 261 (1980); Rothschild, Going Private, Singer, and Rule 13e-3: What Are the Standards for Fiduciaries, 7 Sec. REg. L.J. 195 (1979); Comment, Delaware Reverses Its Trend in Going Private Transactions: The Forgotten Majority, 11 LoY. L.A.L. REv. 567 (1978); Comment, Singer v. Magnavox and Cash Take-Out Mergers, 64 VA. L. Rev. 1101 (1978). 
tory appraisal remedy; ${ }^{85}$ majority shareholders cannot effect a merger solely for the purpose of eliminating the minority; ${ }^{86}$ such a merger must be for a proper purpose and must be entirely fair to the minority; ${ }^{87}$ a merger made primarily to advance the business purpose of a majority stockholder is proper so long as it has a bona fide purpose and is entirely fair to the minority; ${ }^{88}$ and where a complaint alleges that the purpose of the merger was to eliminate minority shareholders, such a complaint may often be immune from a motion to dismiss. ${ }^{89}$ The foregoing principles are applicable to

85380 A.2d at 978. See Coleman v. Taub, 487 F. Supp. 118 (D. Del. 1980) (applying Delaware law).

${ }^{86}$ Id. 978-80. See Young v. Valhi, Inc., 382 A.2d 1372 (Del. Ch. 1978). In Young, the chancery court issued a preliminary injunction barring the merger and held that, notwithstanding management's assertion that the merger would result in tax savings and the avoidance of future conflicts of interest, "the basic purpose behind the merger now before the Court is effectuation of a long standing decision on the part of Contran to eliminate the minority shares of Valhi by whatever means as might be found to be workable." Id. 1378.

87 Tanzer v. International Gen. Indus., Inc., 379 A.2d 1121, 1124-25 (Del. 1977). The "entire fairness" test applies not only to the price offered for the stock but to "all aspects of the transaction." Id. 1125. See also Securities Act Release Nos. 6100, 6109 (Aug. 1979), in which the SEC adopted Rules 13e-3 and $13 \mathrm{e}-4$ relating to going private transactions by public companies or their affiliates. For a discussion of the fairness aspects of the rules, see note 49 supra.

ss Tanzer, 379 A.2d at 1124-25. Thus, the Tanzer court held:

As a stockholder, IGI [the common parent] need not sacrifice its own interest in dealing with a subsidiary; but that interest must not be suspect as a subterfuge, the real purpose of which is to rid itself of unwanted minority shareholders in the subsidiary. That would be a violation of Singer and any subterfuge or effort to escape its mandate must be scrutinized with care and dealt with by the Trial Court. And, of course, in any event, a bona fide purpose notwithstanding, IGI must be prepared to show that it has met its duty, imposed by Singer and Sterling v. Mayflower Hotel Corp. of "entire fairness" to the minority.

Id. 1124 (citation omitted). One commentator remarks that the recent Delaware cases suggest that a cash-out merger, even though serving no corporate purpose, may, nonetheless, pass scrutiny if it serves a purpose of the fiduciary. Rothschild, supra note 84 , at 215 .

89 See Kemp v. Angel, 381 A.2d 241 (Del. Ch. 1977), in which the chancery court held that where there is a reasonable probability that the minority shareholders might prevail because the merger was unfair, the case must proceed to trial:

[I]t being only at trial that the Court can give the required careful scrutiny to the testimony adduced subject to objection and cross examination as well as to other evidence offered in an orderly fashion and also stest the credibility of witnesses before reaching a determination as to whether or not the transaction under attack is in fact entirely fair to minority stockholders ....

Id. 245. As a later decision held, however, under certain limited circumstances, a complaint attacking a merger may be subject to a motion to dismiss for failure to state a cause of action:

[W] here the terms of the merger are ratified and approved by a majority of those shareholders who otherwise would have been powerless to stop it, and where approval is made to depend on the minority vote, then the 


\section{short-form as well as long-form mergers. ${ }^{90}$}

It remains to be seen whether other states will follow Delaware's lead. For example, the Indiana Supreme Court, relying on Singer, held that the effectuation of a merger that eliminated a minority shareholder, even though in compliance with the technical requirements of the state's merger statute, must advance a corporate purpose in order to withstand attack under Indiana law.91 Similarly, the Supreme Court of Hawaii recently followed the Singer decision, stating that "a merger effected for the sole purpose of freezing out the minority interest is a violation of fiduciary principles." ${ }^{2}$ In contrast, the Pennsylvania Supreme Court recently

Singer rationale is inapplicable and the burden should shift to the complaining member of the minority to show fraud, misrepresentation, or other conduct attributable to the majority shareholder which would warrant setting aside the affirmative vote of the minority for their own benefit.

Weinberger v. UOP, Inc., 409 A.2d 1262, 1268-69 (Del. Ch. 1979). Compare Michaelson v. Duncan, 407 A.2d 211 (Del. 1979).

90 Roland Int'l Corp. v. Najjar, 407 A.2d 1032 (Del. 1979). Applying the Singer principles, the court reasoned that "the need to recognize and enforce such equitable principles is probably greater when the size of the minority is smaller." İ. 1036. The Roland court's holding signifies that an acquiror, in engaging in an integrated two-step transaction for cash of $100 \%$ of the subject company, must show that both steps had a bona fide purpose and treated minority shareholders fairly. Note that this principle creates an apparent inconsistency with SEC Rule 13e-3 which "excepts a second-step transaction effected by an offeror who became an affiliate by virtue of an earlier tender offer, provided that the second-step (clean-up) transaction is effected within a year of the earlier offer on terms at least as favorable to the minority as those in the earlier offer." Rothschild, supra note 84 , at 213 .

91 Gabhart v. Gabhart, 267 Ind. 370, 388, 370 N.E.2d 345, 356 (1977). The Indiana Supreme Court apparently stopped short of adopting the Singer two-step rationale. The Gabhart court stated:

The case before us is similar to the case of Singer v. Magnavox Co. . . . In that case, the Supreme Court of Delaware ... relied upon agency principles of fiduciary duty to hold that a corporate merger is subject to judicial scrutiny concerning its "entire fairness" to minority shareholders. We see no need to go that far in deciding the question before us. Under the Delaware view, it appears that every proposed merger would be subject to having its bona fides determined by judicial review. We do not believe the judiciary should intrude into corporate management to that extent.

267 Ind. at 388, 370 N.E.2d at 356. See Rothschild, supra note 84, at 215-16. See also Jones v. H. F. Ahmanson \& Co., 1 Cal. 3d 93, 108, 81 Cal. Rptr. 592, 599, 460 P.2d 464, 471 (1969) ("[a]ny use to which [majority shareholders] put the corporation or their power to control the corporation must benefit all shareholders proportionately and must not conflict with the proper conduct of the corporation's business"). As interpreted by the Hawaii Supreme Court, "[a]lthough Ahmanson did not involve a merger, it appears clear from the language of the opinion that the California Supreme Court would apply the fiduciary duty of good faith and inherent fairness to such a situation." Perl v. IU Int'l Corp., 607 P.2d 1036, 1047 n.12 (Hawaii 1980).

92 Perl v. IU Int'I Corp., 607 P.2d 1036, 1046 (Hawaii 1980). The Hawaii Supreme Court acknowledged that the situation in Perl was arguably different 
held that appraisal is the sole postmerger remedy under that state's law for aggrieved minority shareholders. ${ }^{93}$ Although the court was "not unmindful of the grave unfairness and fraud frequently present in mergers of this type, especially where there is a 'cash-out' of the minority stockholders," 94 it concluded that the state legislature intended that the appraisal statute serve as the sole postmerger remedy. The court recognized, however, the minority's right in the premerger period to seek injunctive relief to prevent the merger's consummation. $^{95}$ The majority's holding occasioned a vigorous dissent that relied on Delaware case law to assert that "stockholders who allege that a merger is "fraught with fraud or fundamental unfairness' should be permitted to challenge the validity of said merger at any time, including post-merger." 96 Importantly, however, the Pennsylvania, Delaware, and other decisions all indicate that aggrieved shareholders may bring suit in state court to enjoin a merger that has not been consummated. Based on the rebirth of these fiduciary principles, Santa $F e$ might have been decided differently today.$^{97}$

from the Delaware cases in that the minority shareholders were not literally squeezed out. The court refused to distinguish the Delaware cases on this basis, reasoning that

[i]t makes little sense . . to to condemn cash out mergers on the one hand, and yet to permit mergers using preferred securities redeemable at the option of the majority on the other if the minority may be just as effectively eliminated from the corporation by the redemption of the stock as by the straight cash out method.

Id. 1047-48. See generally Gillerman, The Corporate Fiduciary Under State Law, 3 Corp. L. Rev. 299 (1980); Note, Partial and Selective Reacquisitions of Corporate Securities, 15 CAL. WEST. L. REv. 264 (1979).

93 In re Jones \& Laughlin Steel Corp., 412 A.2d 1099 (1980). For a discussion of this case, see 549 SEc. REg. \& L. Rep. (BNA) A-6 (April 16, 1980).

94412 A.2d at 1104 .

95 Id. 1103-04. See also Dower v. Mosser Indus., Inc., 488 F. Supp. 1328 (E.D. Pa. 1980) (company that merged into a newly created subsidiary to eliminate minority stockholders interests did not violate $\$ 10(\mathrm{~b})$ and rule $10 \mathrm{~b}-5$ or state law prohibiting breaches of fiduciary duty), discussed in 553 SEC. REG. L. Rep. (BNA) A-5 (May 14, 1980).

96412 A.2d at 1105 (Larsen, J., dissenting) (emphasis in original) (citing as persuasive Roland Int'l Corp. v. Najjar, 407 A.2d 1032 (Del. 1979)). See note 90 supra.

97 See Roland Int'l Corp. v. Najjar, 407 A.2d 1032 (Del. 1979), which involved a short-form merger. Applying the "bona fide purpose" and "entire fairness" principles of Singer, the court upheld a minority shareholder's complaint because appraisal was no longer the sole remedy. See note 90 supra \& accompanying text. 


\section{Post-Santa Fe Decisions in the Federal Courts}

\section{A. Federal Disclosure Requirements Based on State Law Claims-The Goldberg Rationale}

After the Singer line of cases, and similar developments in other jurisdictions, minority shareholders in situations like Santa $F e$ not only can enforce their right to seek redress under state law, but can obtain under federal law, subject to certain limitations, information needed to determine whether management has breached its fiduciary duty under state law. ${ }^{98}$ Failure to provide this information, according to a number of courts, ${ }^{99}$ may be a material deception actionable under section $10(\mathrm{~b})$. This federal right to information extends well beyond the freeze-out merger situation. Indeed, subject to certain caveats, it encompasses every corporate transaction in securities that shareholders could have attacked under state law, had they known the facts. Since Santa $F$ e, five appellate decisionsin the Second, Third, Fifth, Seventh, and Ninth Circuits-have recognized such a right. ${ }^{100}$ These five cases warrant closer examination. Although involving a variety of factual settings, the decisions represent a coherent and consistent approach to Santa Fe's footnote fourteen.

Goldberg $v$. Meridor ${ }^{101}$ involved a subsidiary's sale of part of its stock to its parent in exchange for certain assets. The plaintiff, a minority shareholder of the subsidiary, alleged that the parent's assets had been grossly overvalued and that the subsidiary had been looted. ${ }^{102}$ The plaintiff filed his derivative action prior to Santa Fe and, after amending his complaint in response to the Supreme Court's decision, based his claim of deception on the failure of the interested parent and its management to reveal facts that, if disclosed, would have enabled the minority stockholders to enjoin the transaction in a New York state court. The plaintiff also claimed that allegedly false press releases issued by the parent when the transaction was consummated had lulled the minority shareholders into inaction. ${ }^{103}$

98 This federal right, however, is subject to certain caveats. See notes 12663 infra \& accompanying text.

${ }^{99}$ See notes 100-26 infra \& accompanying text.

100 See Healey v. Catalyst Recovery, Inc., 616 F.2d 64I (3d Cir. 1980); Alabama Farm Bureau Mut. Cas. Co. v. American Fidelity Life Ins. Co., 606 F.2d 602 (5th Cir. 1979), cert. denied, 101 S. Ct. 77 (1980); Kidwell ex rel. Penfold v. Meikle, 597 F.2d 1273 (9th Cir. 1979); Goldberg v. Meridor, 567 F.2d 209 (2d Cir. 1977), cert. denied, 434 U.S. 1069 (1978); Wright v. Heizer Corp., 560 F.2d 237 (7th Cir. 1977), cert. denied, 434 U.S. 1066 (1978).

101567 F.2d 209 (2d Cir. 1977), cert. denied, 434 U.S. 1069 (1978).

102 Id. 211.

103 Id. 
The Second Circuit held that the plaintiff's complaint properly stated a cause of action under rule $10 \mathrm{~b}-5$. The court observed that " $[\mathrm{t}]$ he problem with the application of $\S 10(\mathrm{~b})$ and Rule $10 \mathrm{~b}-5$ to derivative actions has lain in the degree to which the knowledge of officers and directors must be attributed to the corporation, thereby negating the element of deception." 104 The court found the deception requirement satisfied by refusing to attribute the knowledge of management to the corporation because management was not disinterested-a theory of deception based on a long line of pre-Santa $F e$ cases. ${ }^{105}$ The court went on to find that if the facts were as the plaintiff alleged, and if timely disclosure of these facts had been made, then the minority shareholders could have brought suit to enjoin the transaction under New York law. ${ }^{106}$ Consequently, the

$104 I d .215$.

105 Id. For this theory of deception, the Second Circuit relied on several of its earlier decisions: Schlick v. Penn-Dixie Cement Corp., 507 F.2d 374 (2d Cir. 1974), cert. denied, 421 U.S. 976 (1975); Drachman v. Harvey, 453 F.2d 722 (2d Cir. 1972) (en banc); Schoenbaum v. Firstbrook, 405 F.2d 215 (2d Cir. 1968) (en banc), cert. denied, 395 U.S. 906 (1969); Ruckle v. Roto Am. Corp., 339 F.2d 24 (2d Cir. 1964). See also Shell v. Hensley, 430 F.2d 819 (5th Cir. 1970); Pappas v. Moss, 393 F.2d 865 (3d Cir. 1968); Dasho v. Susquehanna Corp., 380 F.2d 262 (7th Cir.) (concurring opinion), cert. denied, 389 U.S. 977 (1967).

100 Id. 219. See also the Second Circuit's statement in SEC v. Parklane Hosiery

Co., Inc., 558 F.2d 1083 (2d Cir. 1977). There, the court asserted that

had the shareholders of Parklane been aware of Somekh's reasons for the going private transaction, they, or others, might well have been able to enjoin the merger under New York law as having been undertaken for no valid corporate purpose. . . . This case involves a failure to disclose when the non-disclosed information could have been used by the minority shareholders to attempt to enjoin the merger.

Id. 1088.

The Goldberg majority evoked a strong dissent from Judge Meskill, who argued that "the majority has neatly undone the holdings of Green, Piper and Cort by creating a federal cause of action for a breach of fiduciary duty that will apply in all cases, save for those rare instances where the fiduciary denounces himself in advance." Id. 225 (Meskill, J., dissenting). Reflecting on Goldberg's significance, one commentator opined:

[G]eneral application of the standard will allow a large number of suits involving breach of fiduciary duties against corporate directors into federal court under rule 10b-5. . . . A federal cause of action will thus arise whenever a fiduciary opts not to disclose facts that the minority could use to enjoin him.

Note, 46 GEo. WASF. L. REv. 861, 875 (1978). For other law review articles discussing Goldberg, see Block \& Schwarzfeld, Corporate Mismanagement and Breach of Fiduciary Duty After Santa Fe v. Green, 2 Corp. L. REv. 91 (1979); Campbell, Santa Fe Industries, Inc. v. Green: An Analysis Two Years Later, 30 ManNe L. REv. 187 (1979); Hazen, supra note 19; Jacobs, Rule 10b-5 and Self Dealing By Corporate Fiduciaries: An Analysis, 48 U. CIN. L. Rev. 643 (1979); Sherrard, Federal Judicial and Regulatory Responses to Santa $\mathrm{Fe}$ Industries, Inc. v. Green, 35 WASE. \& LEE I. REV. 695 (1978); Note, Suits for Breach of Fiduciary Duty Under Rule 10b-5 After Santa Fe Industries, Inc. v. Green, 91 Harv. L. REv. 1874 (1978); Note, Goldberg v. Meridor: The Second Circuit's Resurrection of Rule 10b-5 Liability for Breaches of Corporate Fiduciary Duties to Minority 
case was distinguishable from Santa Fe, and the plaintiff's complaint stated a cause of action under rule $10 \mathrm{~b}-5$.

Recently, the Second Circuit reaffirmed the Goldberg rationale in IIT v. Cornfeld,,$^{107}$ in which the court held actionable under rule $10 \mathrm{~b}-5$ an alleged deception of a foreign mutual fund through misleading disclosure of material facts. Quoting from Goldberg, the court stated that "an action under Rule $10 \mathrm{~b}-5$ can lie if 'there is deception of the corporation (in effect, of its minority shareholders) when the corporation is influenced by its controlling shareholder to engage in a transaction adverse to the corporation's interests (in effect, the minority shareholders' interests) and there is nondisclosure or misleading disclosures as to the material facts of the transaction." " 108

The Seventh Circuit case, Wright v. Heizer Corp., ${ }^{109}$ also involved an action by minority shareholders of a subsidiary against the parent corporation. The plaintiffs sought to set aside the subsidiary's pledge of its most valuable asset, stock in a third corporation, as collateral for a loan procured by the subsidiary from the parent. The evidence indicated that the transaction had been arranged in order to allow the parent to foreclose on the pledged stock, an action the parent intended to take if minority shareholders were successful in related litigation involving the subsidiary. ${ }^{110}$

The district court, writing before the Supreme Court's decision in Santa Fe, held the pledge invalid under rule 10b-5 because of overreaching and unfairness. ${ }^{111}$ The Seventh Circuit, faced with Santa $F e$, adopted another rationale. The court first observed that under applicable Delaware law pledges do not require shareholder approval.112 It therefore found that "under rule 10b-5 disclosure to . . . [the pledgor-subsidiary's] board of directors would be sufficient, unless Heizer [the parent] controlled the board to such an extent that only the independent shareholders were able to safeguard the corporation's interests." 113 Concluding that there was

Shareholders, 64 VA. L. Rev. 765 (1978). See also Borden, "Predict sue 'fact" Doctrine Demise: A Threat to Corporate Management," N.Y.L.J., Dec. 15, 1980, at 29 , col. 2.

107619 F.2d 909 (2d Cir. 1980).

108 Id. 917.

109560 F.2d 236 (7th Cir. 1977), cert. denied, 434 U.S. 1066 (1978).

110 Id. $244-45,248-49$.

111 Wright v. Heizer Corp., 411 F. Supp. 23 (N.D. Ill. 1975).

112560 F.2d at 248.

113 Id. (citations omitted). The court also stated as a general principle: "When an entire board of directors is controlled by a self-dealing director or shareholder the corporation can only be represented by the independent share- 
such control, and that under Delaware law Heizer had a fiduciary duty to deal fairly with the subsidiary-a duty that the minority shareholders could have enforced in a state court ${ }^{114}$-the court reasoned: "Under these circumstances, Heizer was obliged to disclose the material facts concerning the transaction to the independent shareholders prior to its consummation. This obligation was not fulfilled: the shareholders were first informed of the general terms of the pledge and the reasons therefor two months after the transaction." 115

Sweeping relief was granted. The subsidiary's wrongfullyobtained pledge was nullified, reducing Heizer to the position of a

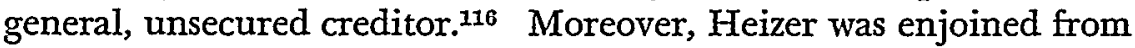
entering into any securities transaction with its subsidiary without first complying with several court-ordered restrictions. ${ }^{117}$

The Ninth Circuit's decision in Kidwell ex rel. Penfold $v$. Meikle, following Goldberg and Wright, held that inadequate disclosure by interested directors may give rise to a federal claim under rule $10 \mathrm{~b}-5 .{ }^{118}$ The court, noting the apparent availability of state court injunctive relief, reasoned that "[i] nadequate disclosures lull into security those shareholders who might bring derivative actions under state law to enjoin the securities transactions if all material facts were revealed." 119

In Alabama Farm Bureau Mutual Casualty Co. v. American Fidelity Life Insurance Co., ${ }^{120}$ the Fifth Circuit became the fourth federal appellate court to distinguish Santa $F e$ 's prohibition against employing rule $10 \mathrm{~b}-5$ to redress claims based essentially on breaches of fiduciary duty. The case involved a corporation's repurchase of its own stock as part of management's alleged attempt to perpetuate its control of the company by artificially raising the market price of its stock, thereby discouraging takeover attempts. The defendants allegedly failed to disclose this inflationary effect of the stock repurchase plan on the market price of the corporation's outstanding shares. ${ }^{121}$ Adopting the Goldberg rationale, the Fifth Gircuit held

holders, to whom full disclosure must be made. Conversely, where disinterested directors constitute a majority of the board of directors, disclosure to the board is sufficient." Id. 249 (citations omitted).

114 Id. 251.

115 Id. 249 (emphasis added).

116 Id. 253.

117 Id. 255-56.

(1980).

118597 F.2d 1273, 1290-97 (9th Cir. 1979). See 14 U. Rrcr. L. Rev. 588

119 Id. 1292.

120606 F.2d 602 (5th Cir. 1979), cert. denied, 101 S. Ct. 77 (1980).

121 Id. 606-07. 
that this nondisclosure, coupled with the possible availability of injunctive relief from a state court, provided the basis for a derivative action based on deception under rule $10 \mathrm{~b}-5 .{ }^{122}$

In another recent decision, Healey $v$. Catalyst Recovery, Inc., ${ }^{123}$ the defendants, controlling shareholders, sought to merge the subject company into a second corporation that they also controlled. Their plans were opposed by a twenty percent minority shareholder of the subject company who requested and was refused information regarding the second corporation. After the merger was effected, the minority shareholder brought suit under rule 10b-5.124 Plaintiff successfully argued that he was a "seller" of securities and had been deceived by defendants' nondisclosure. ${ }^{125}$ Healey is therefore distinguishable from the four cases discussed above because they involved derivative actions claiming that a corporation had been deceived. Despite this altered fact pattern, the Third Circuit adopted the Goldberg rationale and held that "where a misrepresentation or omission of material information deprives a proper plaintiff minority shareholder of an opportunity under state law to enjoin a merger, there is a cause of action under rule 10b-5." 126

Given a broad reading, these cases may appear to hold that a breach of fiduciary duty, coupled with misrepresentation or nondisclosure, that would have entitled the complainant to seek state court relief to enjoin the contemplated transaction is a sufficient basis upon which a post-Santa $F e$ federal claim may be predicated. The ensuing discussion reveals, however, that this general principle is subject to a number of caveats.

\section{B. Caveats to the Goldberg Rationale}

For the lawyer who counsels management, the post-Santa Fe cases present the dilemma of whether his client will be served best by full advance disclosure to minority stockholders whenever management is involved in a conflict of interest situation without the

122 Id. 614-15. Dissenting, Judge Skelton asserted that the case did not involve deception. Indeed, it was "much ado about nothing and border[ed] on being frivolous." Id. $618 \mathrm{n} .1$.

123616 F.2d 641 (3d Cir. 1980).

124 Id. 645.

125 Id. 647.

${ }^{126} I d$. Judge Aldisbert dissented, arguing that Santa Fe's reasoning applied to the case at bar. He concluded, "[b]ecause I cannot justify the majority's bold action in "federaliz[ing] [a] substantial portion of the law of corporations that deals with transactions in securities," .. I dissent." Id. 661 (quoting Santa Fe Indus., Inc. v. Green, 430 U.S. 462, 479 (1977)). But see Merritt v. Colonial Foods, Inc., [Current] FED. SEC. L. REP. (CCH) 『 97,689 (D. Del. Sept. 19, 1980), in which the district court followed Healey in distinguishing Santa Fe. 
input of an independent and disinterested board of directors. Advance disclosure may result, of course, in a state law action for breach of fiduciary duty; ${ }^{127}$ absent such disclosure, however, a rule $10 \mathrm{~b}-5$ violation may ensue. In any event, advance disclosure does not require that management indict itself. ${ }^{128}$ As Professor Ratner has observed: "It is not necessary to say, "This is a grossly unfair transaction in which the board of directors is overreaching the minority stockholders.' You just have to give them the facts." 129

For the lawyer consulted by a victim of corporate skullduggery, Santa $\mathrm{Fe}$ and its progeny demonstrate that the disclosures made by management must be examined with painful care; that, in certain situations, rule $10 \mathrm{~b}-5$ is alive and well; that, although unfairness alone is an insufficient basis for a federal claim, there are circumstances, subject to certain limitations, in which unfairness coupled with either a failure to disclose or an affirmative deception remains a firm foundation for a federal claim; and that in such situations counsel may have a choice between a state forum and a federal one.

Counsel, however, should not leap to the conclusion that he has this choice of forum. He must remember the general rule that corporations are managed by their directors and not by their shareholders, ${ }^{130}$ and that management's knowledge may be attributed to the corporation, thus precluding a finding of deception. ${ }^{131}$ Even before Santa $F e$, rule $10 \mathrm{~b}-5$ claims alleging that a corporation had been deceived required proof that the corporation was "disabled from availing itself of an informed judgment on the part of its

127 See note 106 supra \& accompanying text.

128 See, e.g., Rodman v. Grant Foundation, 608 F.2d 64, 70 (2d Cir. 1979); Alabama Farm, 606 F.2d at 611; Golub v. PPD Corp., 576 F.2d 759, 765 (8th Cir. 1978); Gluck v. Agemian, 495 F. Supp. 1209, 1214-16 (S.D.N.Y. 1980); Goldberger v. Baker, 442 F. Supp. 659, 667 (S.D.N.Y. 1977). As stated by the Fifth Circuit: "When the nature and scope of a transaction are clear, it is not necessary for the corporate instigators to characterize the various effects of the transaction as favorable or unfavorable or to evaluate its overall effect; such characterization is a matter of judgment, not fact." Alabama Farm, 606 F.2d at 611. See also note 136 infra. But see Vaughn v. Teledyne, Inc., in which the Ninth Circuit stated: "Corporate officials are under no duty to disclose their precise motive or purpose for engaging in a particular course of corporate action, so long as the motive is not manipulative or deceptive and the nature and scope of any stock transactions are adequately disclosed to those involved." 628 F.2d 1214, 1221 (9th Cir. 1980) (emphasis added).

129 Ratner, supra note 6, at 322. See also Rodman v. Grant Foundation, 608 F.2d 64, 70-72 (2d Cir. 1979); Bertoglio v. Texas Int'I Co., 488 F. Supp. 630 (D. Del. 1980); Amalgamated Clothing and Textile Workers Union v. J.P. Stevens, 475 F. Supp. 328 (S.D.N.Y. 1979).

${ }^{130}$ See Burks v. Lasker, 441 U.S. 471, 478 (1979); Santa Fe, 430 U.S. at 479; Cort v. Ash, 422 U.S. 66, 84 (1975).

131 See notes $104 \& 105$ supra \& accompanying text. 
board regarding the merits of the transaction." 132 The need for a showing of disability is clearer today than ever before. For example, in Biesenbach $v$. Guenther, ${ }^{133}$ a claim of deception based solely on the allegation that shareholders were not informed of management's breaches of state law fiduciary duties was dismissed for legal insufficiency. To hold otherwise, the Third Circuit reasoned, "would clearly circumvent the Supreme Court's holding in Santa Fe." ${ }^{134}$ Similarly, in Maldonado v. Flynn, ${ }^{135}$ the Second Circuit upheld the dismissal of a rule 10b-5 claim based on the distinterested directors' decision to modify a stock option plan so as to benefit part of the corporation's management at the shareholders' expense. In so holding, the Second Circuit reasoned that since the amendments modifying the stock option plan were "validly enacted by a vote of disinterested board members who had been fully informed of all material facts, their knowledge was attributable to the Corporation and no 'deception' occurred within the meaning of Rule 10b-5." 136

132 Superintendent of Ins. v. Bankers Life \& Cas. Co., 404 U.S. 6, 13 (1971) (quoting with approval Shell v. Hensley, 430 F.2d 819, 827 (5th Cir. 1970)).

133588 F.2d 400 (3d Cir. 1978).

134 Id. 402. Thus, the court stated:

Santa $\mathrm{Fe}$ made clear that absent deception, misrepresentation, or nondisclosure a breach of fiduciary duty does not violate the statute or Rule. . . . In effect, appellants are stating that the failure to disclose the breach of fiduciary duty is a misrepresentation sufficient to constitute a violation of the Act. We refuse to adopt this approach which would clearly circumvent the Supreme Court's holding in Santa Fe. As Judge Higginbotham has reiterated:

[I]t is bemusing, and ultimately pointless, to charge that directors perpetrated a 'material omission' when they failed to (a) discover and adjudge faithless motives for their actions and (b) announce such a discovery in reporting the products of their managerial efforts and judgment. The securities laws, while their central insistence is upon disclosure, were never intended to attempt any such measures of psychoanalysis or reported self-analysis. The unclean heart of a director is not actionable, whether or not it is 'disclosed,' unless the impurities are translated into actionable deeds or omissions both objective and external ....

Id., (quoting Stedman v. Storer, 308 F. Supp. 881, 887 (S.D.N.Y. 1969)), quoted in Lavin v. Data Systems Analysis, Inc., 443 F. Supp. 104, 107 (E. D. Pa. 1977), aff'd, 578 F.2d 1374 (3d Cir. 1978). Accord, Kirtz v. Wiggin, 483 F. Supp. 148, 151 (E.D. Mo. 1980) (" $[t]$ he mere fact, if so, that plaintiffs, as minority stockholders, had not theretofore been told nor were aware of the alleged self-dealing may not be equated with 'deceptive practices' or 'omissions' in the Section 10 (b) sense").

135597 F.2d 789 (2d Cir. 1979).

138 Id. 795 (emphasis added). See Selk v. St. Paul Ammonia Prods., Inc., 597 F.2d 635, 639 (8th Cir. 1979) (failure to disclose that purpose of merger was to freeze out minority shareholders not actionable under $\$ \S 10(\mathrm{~b})$ and $14(\mathrm{a})$ ); O'Brien v. Continental Ill. Nat'l Bank \& Trust Co., 593 F.2d 54, 60 (7th Cir. 1979) (failure to reveal that investment advice was self-serving not actionable under 10(b)); Goldberg, 567 F.2d at 218 n.8 ("We do not mean to suggest that 
Indeed, a careful reading of the Goldberg line of cases reveals that in actions alleging "deception" the courts have consistently required rule $10 \mathrm{~b}-5$ claims to allege more than the bare availability of state court injunctive relief. In derivative actions, when shareholder approval of a transaction is not required, the courts have reasoned that disclosure to a disinterested board of directors is equivalent to disclosure to the shareholders. Stated differently, the knowledge of the disinterested board is attributed to the corporation, thereby precluding a finding of deception. ${ }^{137}$ Of course, in nonderivative actions, such as Healey, where an individual shareholder is the purchaser or seller of securities, a 10b-5 claim need only allege that the shareholder was deceived.13s Under Healey, the deception requirement is satisfied by alleging that there was a material misrepresentation or nondisclosure in the flow of information between the majority and the individual shareholder that deprived the plaintiff of an opportunity under state law to enjoin the merger. ${ }^{139}$

A troublesome issue in determining whether a corporation has been deceived is the proper definition of a "disinterested" director. As the Second Circuit held in Maldonado, a director's "financial stake" in the subject transaction would clearly render him "inter-

$\$ 10(\mathrm{~b})$ or Rule $10 \mathrm{~b}-5$ requires insiders to characterize conflict of interest transactions with pejorative nouns or adjectives"). Bucher v. Shumway, [1979-80 Transfer Binder] FED. SEC. L. REP. (CCH) $\uparrow 97,142$, at 96,299-300 (S.D.N.Y. 1979), aff'd, 622 F.2d 572 (2d Cir.), cert. denied, 101 S. Ct. 120 (1980) (failure to disclose that true purpose of tender offer was to consolidate management's control not actionable under $\$ \S 10(\mathrm{~b})$ and $14(\mathrm{e}))$; Hundahl v. United Benefit Life Ins. Co., 465 F. Supp. 1349, 1364 (N.D. Tex. 1979) (failure to disclose breach of fiduciary duty of scheme to undervalue company not actionable under $\$ 10(\mathrm{~b}))$. See also cases cited in note 128 supra.

Under certain limited circumstances, courts may require that management's "true purpose" be disclosed. Thus in Rodman v. Grant Foundation, 608 F.2d 64 (2d Cir. 1979), the Second Circuit stated that "[i]n the absence of some ulterior wrongful design hinging upon so-called 'entrenchment,' the directors were not required to put forth in proxy materials an analysis of their otherwise obvious interest in company control." Id. 71 (emphasis added). Similarly, in the Alabama Farm case, the Fifth Circuit concluded that an allegation that management had failed to disclose that it "had embarked on a program of maintaining control at the cost of inflating stock prices" involved material information under $\$ 10$ (b). 606 F.2d at 614. Although difficult to pinpoint, these cases may stand for the proposition that when management has an ulterior wrongful design in embarking on a particular course of conduct, disclosure of that design is required. Language contained in the Ninth Circuit's Vaughn v. Teledyne, Inc., decision appears consistent with this assertion. See note 128 supra.

${ }^{137}$ See, e.g., Maldonado, 597 F.2d at 793; Kaplan v. Bennett, 465 F. Supp. 555, 565-66 (S.D.N.Y. 1979).

138 See text accompanying notes 123-26 supra.

138 Healey, 616 F.2d at 646 . The court further stated that "[b]ecause this result Alows from misinformation that harms the plaintiff, it is precisely the type of situation to which rule $10 \mathrm{~b}-5$ is addressed." Id. 
ested." 140 What is not so clear is whether the presence of some other disability, such as a director's desire to maintain his position irrespective of the corporation's best interests, or the perpetration of improper influence or deception upon a director by a controlling person, including the failure to apprise a director of material facts, would likewise render the director "interested." Although some courts have held that only the existence of a financial conflict disqualifies the director, ${ }^{141}$ the better view is that other disabilities have the same effect. ${ }^{142}$ The crucial criterion should not be whether a director is financially interested, but whether he can exercise independent judgment on behalf of the corporation and its shareholders. Any conflict or disability that impairs a director's judgment poses the same threat to the best interests of the corporation and shareholders, regardless of whether it is financially based..$^{143}$ Thus, a showing that a director has a conflict of interest-whether financially related, status-oriented, or otherwise-or that he is acting under some other disability, should prevent him from representing the corporation for purposes of rule 10b-5 disclosure.

Further, the term "disinterested" should be narrowly construed. For example, if a corporation's outside counsel sits on the board, there may be instances in which counsel will be subject to pressure from interested directors. This may occur if some directors have a strong interest in a contemplated transaction and if counsel derives substantial income from his representation. The same reasoning applies to major business suppliers of a corporation. Truly independent actions by either the lawyer or supplier might well signify a substantial reduction in revenue. This coercion, although argu-

140597 F.2d at 793 (citing Falkenberg v. Baldwin, [1977-78 Transfer Binder] FEd. SEC. L. ReP. (CCH) $\{96,086$, at 91,911 (S.D.N.Y. 1977)).

141 See, e.g., Tyco Labs., Inc. v. Kimball, 444 F. Supp. 292 (E.D. Pa. 1977) (directors held to be disinterested where their alleged interest in subject transaction was to perpetuate control).

- 142 Although in Maldonado the Second Circuit defined "disinterested" as the lack of any financial stake in the subject transaction, 597 F.2d at 793, the court also stated that "[d]omination or control of a corporation or of its board by those benefiting from the board's action may under some circumstances preclude its directors from being disinterested." Id. 795. See Kaplan v. Bennett, 465 F. Supp. 555, 565 (S.D.N.Y. 1979); Goldberger v. Baker, 442 F. Supp. 659, 665 (S.D.N.Y. 1977).

143 See generally Maldonado, 597 F.2d at 794 n.5 ("Nonattribution [of the directors' knowledge to the shareholders for purposes of rule 10b-5] is justified when, because of the nature of the transaction, directors cannot be relied upon to represent the interests of shareholders fairly or when an external authority, the state, the incorporators, or the shareholders, have decreed that the directors cannot speak for the corporation."). See also, e.g., Schoenbaum v. Firstbrook, 405 F.2d 215, 219-20 (2d Cir. 1968), cert. denied, 395 U.S. 906 (1969); Pappas v. Moss, 393 F.2d 865, 869 (3d Cir. 1968); Ruckle v. Roto Am. Corp., 339 F.2d 24, 29 (2d Cir. 1964). 
ably subtle, should foreclose labelling either the lawyer or the supplier "disinterested." 144

The preceding discussion outlines a significant limitation of the Goldberg rationale. Only if corporate action requires shareholder approval, or if the directors are interested, ${ }^{145}$ will nondisclosure provide the basis for a claim of deception of a corporation in a derivative action under rule $10 \mathrm{~b}-5 .{ }^{146}$ Even in such cases, however, the bare allegation of nondisclosure will not suffice to state a federal claim. ${ }^{\mathbf{1 4 7}}$ A second limitation imposed by Santa $F e$ is that the aggrieved shareholder may also be required to allege that, had the corporate malfeasance been disclosed, state court remedies would have been available. ${ }^{148}$ In this vein, a question left unanswered after Santa $\mathrm{Fe}$ is whether the complainant must show not only that a suit in state court could have been brought, but also that such a suit would have been won. The courts are split on this issue. ${ }^{149}$ While the Ninth Circuit seems to require that the complainant show that he would have been awarded relief in the state court action, ${ }^{150}$ the Second Circuit appears to require only the bare avail-

144 In Maldonado, however, the Second Circuit concluded that a director who was a partner in a law firm that received substantial fees from the subject corporation was "disinterested." The court reasoned:

[T]o label . . . [counsel] an 'interested' director for purposes of Rule $10 \mathrm{~b}-5$ because of his relationship as the company's legal counsel would be to open the door to an unworkable standard for determining whether there has been deception practiced upon the corporation. ... [W] [We cannot assume that a counsel-director acts for reasons that are against the corporation's interest, as distinguished from the private interests of its officers.

597 F.2d at 794 .

The role and number of outside directors is not a novel concern. Nearly a half-century ago, Justice Douglas described and offered a solution to the problem:

[B]oards wholly or dominantly filled with "shirtsleeve" directors drawn from the executive management, without outside representation, are apt to suffer from myopia and lack of perspective. It is one thing to operate a business efficiently, but it is quite another to be sufficiently detached from the business to be able to see it in relation to its competitors, trade trends, and the like. ... The minimal requirements in this regard are statutory provisions that a majority of the board shall be composed of stockholders who are not employees or officers of the corporation . . . .

Douglas, Directors Who Do Not Direct, 47 HARv. L. Rev. 1305, 1313-15 (1934). See Speech by SEC Chairman Harold M. Williams, "The Role of Inside Counsel in Corporate Accountability," [Current] FED. SEc. L. REP. (CCH) I 82,318, at 82, 374-75 (Oct. 4, 1979). See also Ferrara \& Steinberg, The Role of Inside Counsel in the Corporate Accountability Process, 4 Conp. L. REv. 3 (1981).

145 See notes 136-44 supra \& accompanying text.

146 See cases cited in note 100 supra.

147 See Santa Fe, 430 U.S. at 474 n.14; cases cited in note 100 supra.

148430 U.S. at 474 n.14.

149 See notes 150-63 infra \& accompanying text.

150 See Kidwell, 597 F.2d at 1294. 
ability of such a state action. ${ }^{151}$ Between these two extremes are the Third and Fifth Circuits. Whereas the Fifth Circuit requires the plaintiff to show "a reasonable basis for state relief," 152 the Third Circuit's standard appears slightly more stringent, requiring the plaintiff to demonstrate "a reasonable probability of ultimate success." 153

The formulation of a proper standard is a difficult task. The maintenance of actions along the lines of Goldberg ${ }^{154}$ is dependent largely upon the applicable state law of fiduciary duty. Only if the at 219.

151 See IIT v. Cornfeld, 619 F.2d 909 (2d Cir. 1980); Goldberg, 567 F.2d

152 Alabama Farm, 606 F.2d at 614 (emphasis added). The court stated:

We hold that all that is required to establish $10 \mathrm{~b}-5$ liability is a showing that state law remedies were available and that the facts shown must make out a prima facie case for relief; it is not necessary to go further and prove that the state action would have been successful. . . . [T]he plaintiff must show that there is at least a reasonable basis for state relief, but need not prove that the state suit would in fact have been successful.

The Third Circuit's position taken in Healey, see note 153 infra, and the Fifth Circuit's position in Alabama Farm, appear more stringent than requiring the complainant to survive a rule $12(\mathrm{~b})(6)$ motion under the Federal Rules of Civil Procedure for failure to state a claim upon which relief can be granted, or to survive a motion under rule 56 for summary judgment. Compare the Healey and Alabama Farm standards with the discussion below of rules $12(b)(6)$ and 56:

The Rule $12(b)(6)$ motion also must be distinguished from a motion for summary judgment under Rule 56 , which goes to the merits of the claim and is designed to test whether there is a genuine issue of material fact. The Rule 12(b)(6) motion, as has been mentioned above, only tests whether the claim has been adequately stated in the complaint. Thus, on a motion under Rule $12(\mathrm{~b})(6)$, the court's inquiry essentially is limited to the content of the complaint; summary judgment, on the other hand, involves the use of pleadings, depositions, answers to interrogatories, and affidavits. This distinction between the two provisions is not substantial, however, because Rule $12(\mathrm{~b})(6)$ provides that if "matters outside the pleadings are presented to and not excluded by the court, the motion shall be treated as one for summary judgment . . .."

5 C. Wright \& A. Milleg, Federal Practice and Procedure $\$ 1356$ (1969).

153 Healey, 616 F.2d at 647 (emphasis added). Thus, the Third Circuit adopted a standard somewhat similar to that enunciated by the Fifth Circuit. The court stated:

We ... hold that in a case such as this the plaintiff must demonstrate that at the time of the misrepresentation or omission, there was a reasonable probability of ultimate success in securing an injunction had there been no misrepresentation or omission. ... [W]e frame the test in terms of a reasonable probability for two reasons. First, we believe absolute certainty to be both an impossible goal as well as an impracticable standard for a jury to implement. Second, in most cases the state remedy will be a preliminary injunction, which looks to the likelihood of ultimate success.

Id. See also Wright v. Heizer Corp., 560 F.2d at 250, in which the Seventh Circuit apparently failed to specifically address this question.

154 See generally Campbell, supra note 106, at 192 ("Meridor and Heizer are really cases in which the very nub of the complaint was that the corporation has been treated unfairly by its fiduciaries."). 
relevant state law recognizes the viability of the plaintiff's claim will a federal claim be possible. Under such conditions, the success of the plaintiff's suit may well vary, even within a single federal circuit. $^{165}$ The incongruity of a federal claim-with federal law supposedly uniform and national in character-being dependent on state law is self-evident.

To ameliorate this incongruity, the Second Circuit requires that the complainant show only a bare availability of state court relief.150 This approach recognizes the federal interest in full and fair disclosure. ${ }^{157}$ Critics of this position contend that it may allow circumvention of state court processes, thereby inducing forum shopping. Under the Second Circuit's approach, a plaintiff who would have failed in state court may, by alleging the possibility of success, coupled with nondisclosure, state a valid claim of "deception" within the meaning of rule $10 \mathrm{~b}-5$. This approach is quite expansive, and some courts have argued that it stretches Santa Fe's footnote fourteen beyond its recognizable limits. ${ }^{158}$ On the other hand, making a federal claim completely dependent on state law would emasculate the federal interest in uniformity, ${ }^{159}$ and would place an extremely heavy burden on complainants under rule 10b-5. Further, as noted by the Third Circuit, requiring the plaintiff to prove a state claim may well be an impossible standard to administer. ${ }^{160}$

Although the approaches of the Third and Fifth Gircuits may ease the complainant's burden in proving his rule $10 \mathrm{~b}-5$ claim, they too condition the recognition of such a claim on the status of the applicable state law. ${ }^{\mathbf{1 0 1}}$ Thus, these positions will encourage inconsistent results in similar situations, thereby negating the federal securities law's interest in maintaining uniformity. ${ }^{162}$ Nevertheless,

155 For example, in the Ninth Circuit, which covers nine states, a number of different dispositions could result in cases having similar factual situations, due to the application of different state law.

156 See note 151 supra \& accompanying text.

157 See Santa Fe, 430 U.S. at 477-78. See generally Note, Suits for Breach of Fiduciary Duty Under Rule 10b-5 After Santa Fe Industries, Inc. v. Green, 91 HARv. L. Rev. 1874, I891-93 (1978).

158 See notes 150,152 \& 153 supra \& accompanying text. See generally the commentators cited in note 106 supra.

159 See McClure v. Borne Chem. Co., 292 F.2d 824, 829-35 (3d Cir.), cert. denied, 368 U.S. 939 (1961); Note, supra note 157, at 1889.

160 Healey, 616 F.2d at 647 ( 3 d Cir. 1980).

101 See generally Note, Goldberg v. Meridor: The Second Circuit's Resurrection of Rule 10b-5 Liability for Breaches of Corporate Fiduciary Duties to Minority Shareholders, 64 VA. L. REv. 765, 772-77 (1978).

162 See note 159 supra \& accompanying text. 
the Third and Fifth Circuits' views, although not a perfect solution, represent a workable compromise. That compromise seeks a balance between the Second Circuit's view, which may stretch Santa $F e$ 's footnote fourteen beyond its intended meaning, and the Ninth Circuit's approach, which defines a federal right solely by reference to the application of state law.

An alternative approach would be to vary the degree of proof required according to the state of the record. For example, when no meaningful discovery has been conducted and the record is undeveloped, the Ninth Circuit's requirement of proof of success in a state action would be far too stringent. Conversely, where a complete trial has been held or a lengthy record has been compiled in federal court, a stricter standard arguably should apply. ${ }^{\mathbf{1 0 3}}$ Yet, looking to the state of the record evades the basic issue presented by the post-Santa $F e$ cases. This approach does nothing to address the tension between the federal interest in the uniform application of the federal securities laws and the rationale underlying Santa Fe and footnote fourteen.

\section{Further Reflections on Federalism and InVestor Protection After Santa Fe}

What of federalism and investor protection after Santa Fe? With respect to rule $10 \mathrm{~b}-5$ as well as other provisions of the federal securities laws, the degree of investor protection afforded will depend, in large part, on the applicable state law. ${ }^{164}$ At first glance, it appears that the Goldberg-type ${ }^{165}$ securities and corporation law cases that are brought in the federal courts alleging section $10(\mathrm{~b}) /$ rule $10 \mathrm{~b}-5$ violations present local law questions akin to those with which the federal judiciary grapples in diversity cases governed by

163 See Respondent's Brief in Opposition to the Petition for a Writ of Certiorari at 14-15, Alabama Fidelity Life Ins. Co. v. Alabama Farm Bureau Mut. Cas. Ins. Co., No. 79-1362 (October Term, 1979). Thus, the Ninth Circuit required proof of success on the state law claim where the facts were "gleaned from a lengthy record." Kidwell, 597 F.2d at 1278. The courts which have applied less stringent standards were presented with incomplete factual records.

164 See Burks v. Lasker, 441 U.S. 471 (1979); Cort v. Ash, 422 U.S. 66, 7785 (1975). In Burks, its most recent pronouncement on this subject, the Court remarked that "Congress has never indicated that the entire corpus of state corporation law is to be replaced simply because a plaintiff's cause of action is based upon a federal statute." 441 U.S. at 478. The Court accordingly held that even in a case arising under the Investment Company Act "federal courts should apply state law governing the authority of independent directors to discontinue derivative suits to the extent such law is consistent with the policy of the IInvestment Company and Investment Advisers Acts]." Id. 486.

165 Goldberg v. Meridor, 567 F.2d 209 (2d Cir. 1977), cert. denied, 434 U.S. 1069 (1978). See notes 101-06 supra \& accompanying text. 
the rule of Erie Railroad Co. v. Tompkins.166 Significantly, however, unlike the Erie doctrine, under which federal courts apply state substantive law in order to recognize state created remedies and liabilities, ${ }^{167}$ Santa Fe's footnote fourteen, as construed by the lower federal courts, conditions the existence of a federal right upon the applicable state law..$^{188}$

This limitation, however, may be more apparent than real. In a large number of cases, the applicable state law may be unresolved: for example, the issue may be one of first impression, or the state's high court may not have considered the question. ${ }^{169}$ In such a case, a federal court, although ostensibly predicting how the relevant state's high court would rule on the matter, ${ }^{170}$ may take

166304 U.S. 64, 78 (1938) ("Except in matters governed by the Federal Constitution or by acts of Congress, the law to be applied in any case is the law of the state. And whether the law of the state shall be declared by its Legislature in a statute or by its highest court in a decision is not a matter of federal concern.").

167 See, e.g., Hanna v. Plumer, 380 U.S. 460 (1965); Byrd v. Blue Ridge Rural Elec. Coop., Inc., 356 U.S. 525 (1958); Guaranty Trust Co. v. York, 326 U.S. 99 (1945).

168 For example, in Goldberg v. Meridor, the majority's holding was bottomed on the proposition that the complainant could have gone to a New York state court for an injunction had the alleged facts been known to him in time. Judge Meskill, dissenting in part, doubted the validity of that premise. Noting that both the parent and its allegedly looted subsidiary were Panamanian corporations, Judge Meskill expressed the view that "it is not at all clear that New York law determines the availability of an injunction in this situation." 567 F.2d 209, $224 \mathrm{n} .9$ ( $2 \mathrm{~d}$ Cir. 1977), cert. denied, 434 U.S. 1069 (1978) (Meskill, J., dissenting). The majority opinion responded that "[t]he doubts entertained by our brother as to the existence of injunctive remedies in New York are unfounded," and then observed that "defendants have not brought to our attention any Panamanian ... prohibition against derivative actions." Id. 219-20 (citations omitted). Analogous language is contained in the Ninth Circuit's Kidwell decision instructing "the federal trial judge ... [to] decide any legal issues that would have arisen in the hypothetical state suit." Kidwell ex rel. Penfold v. Meikle, 597 F.2d 1273, 1294 (9th Cir. 1979). Note in this context that, as under Erie, the federal court must not only apply state substantive law but must determine which state law to apply. See generally Day and Zimmerman, Inc. v. Challoner, 423 U.S. 3 (1975); Klaxon Co. v. Stentor Elec. Mfg. Co., Inc., 313 U.S. 487 (1941) (a federal court, in a case governed by the Erie rule, must apply whatever law that the courts of the state in which the federal court sits would apply).

169 Other reasons may include confusion in the state court decisions, a developing line of authorities that casts doubt regarding the state of the law, dicta or ambiguities in state court opinions, and legislative developments that may undermine the judicial rule. Bernhardt v. Polygraphic Co. of Am., 350 U.S. 198, 205 (1956).

170 See Commissioner v. Estate of Bosch, 387 U.S. 456 (1967), in which the Court stated:

[U]nder some conditions, federal authority may not be bound even by an intermediate state appellate court ruling. ... [T]he State's highest court is the best authority on its own law. If there be no decision by that court then federal authorities must apply what they find to be the state 
into account the federal interest in full and fair disclosure. Even if this result follows, the state's countervailing interest in maintaining areas of independence remains intact because the state high court is the final arbiter. The federal court's interpretation of state law is, in essence, merely a recommendation that the state high court can freely accept or reject when it ultimately determines the matter.

It can be argued that some federal courts applying Santa $F e^{\text {'s }}$ footnote fourteen exception will deliberately ignore state law, even when such law has been construed by the relevant state's high court. Such a consequence is possible but unlikely. For example, the federal courts applying the Erie rule have, as a general proposition, satisfactorily determined relevant state law. In all likelihood, this tradition would be generally followed in a Goldberg-type action. ${ }^{171}$

Some commentators have asserted that this application of federalism ultimately will be detrimental to investor interests. Arguing that state fairness principles provide inadequate protection, they predict that concepts of federalism will lead to "[the denial of] effective relief to powerless shareholders." ${ }^{172}$ It should be recognized, however, that the Goldberg line of cases represents an accommodation between competing federal and state interests. On one hand, because business enterprises often have national investor constituencies and national economic significance, the law governing the relationship between these enterprises and constituencies should also be national and uniform. ${ }^{173}$ On the other hand, the fiduciary duties of corporate management traditionally have been defined by state common law, which can be restated, reshaped, and adapted to con-

law after giving 'proper regard' to relevant rulings of other courts of the State.

Id. 465 .

171 See generally C. Wright, HandBoOK OF THE LAW OF Federal Courts $\S 55$, at 258 ( $3 \mathrm{~d}$ ed. 1976). On the other hand, it can be argued that the Second Circuit's rationale in Goldberg, requiring the plaintiff to show only that state court remedies were available, obfuscates the application of state law and may induce forum shopping. See notes 156-58 supra \& accompanying text.

172 Campbell, supra note 106, at 206. See Ratner, supra note 6, at 323 ("the approach the Supreme Court is following now will exclude from the federal courts cases for which there is no effective remedy under state law because of problems of service of process, venue, security for expenses, and other procedural obstacles"). Query whether the substance-procedure distinction applies in this situation, because the outcome is not the only consideration. Even though the application of state procedural mechanisms might preclude relief in the federal action, the federal judicial system, as an independent system, has a countervailing interest in applying its own procedural rules. As such, if the federal procedural mechanisms are constitutional, they may be controlling notwithstanding contrary state provisions. See Hanna v. Plumer, 380 U.S. 460 (1965); Byrd v. Blue Ridge Rural Elec. Coop., Inc., 356 U.S. 525 (1958).

173 See notes 159 \& 162 supra \& accompanying text. 
temporary local needs without legislative change. ${ }^{174}$ Thus, the Goldberg and Singer v. Magnavox ${ }^{175}$ lines of cases indicate that the degree of investor protection in this area may often depend on the interaction between federal and state law. Indeed, a recent series of events suggests that state courts, at times, may be more inclined to protect shareholder interests than federal courts.

In Burks v. Lasker, ${ }^{176}$ the Supreme Court considered whether a quorum of four statutorily disinterested directors within the context of the Investment Company Act ${ }^{177}$ could bar a shareholder's derivative action brought against their fellow directors on the ground that, in exercising their good faith business judgment, the disinterested directors concluded that the continuation of the lawsuit was contrary to the company's best interests. ${ }^{178}$ Rather than directly answering this question, the Supreme Court articulated a two-pronged test. First, it must be determined whether the applicable state laws permit the disinterested directors to bar a shareholder's derivative action against fellow directors. ${ }^{179}$ Second, if the answer to the foregoing is in the affirmative, the federal court must dismiss the suit, "unless the state laws permit actions prohibited by the [federal statute], or unless 'their application would be inconsistent with the federal policy underlying the cause of action." "1so The Court suggested that, under this standard, the policies underlying the Investment Company and Investment Advisers Acts would, in certain circumstances, allow termination of a derivative suit by disinterested directors if state law so permitted. ${ }^{\text {si } 1}$ The Court remanded the case for further proceedings consistent with its opinion, and consideration of what the applicable state law provided. ${ }^{132}$

Maldonado $v$. Flynn, ${ }^{183}$ discussed above in the context of rule 10b-5, also involved a Burks issue. In Maldonado, the plaintiffs

174 See generally Burks v. Lasker, 441 U.S. at 477-78; Santa Fe, 430 U.S. at 477-78.

175 Singer v. Magnavox, 380 A.2d 969 (Del. 1977). See notes 80-84 supra \& accompanying text.

170441 U.S. 471 (1979).

17715 U.S.C. $\$ \$ 80 a-2(a)(19), 80 a-10$ (1976).

178441 U.S. at $473-74$.

$179 \mathrm{Id}$. 478.

180 Id. 479 (quoting Johnson v. Railway Express Agency, 421 U.S. 454, 465 (1975)).

181441 U.S. at 486 . See id. 487 (Blackmun, J., concurring) ("it seems to me that a situation could very well exist where state law conflicts with federal policy"). But see id. 487 (Stewart, J., concurring in the judgment) ("I cannot agree with the implication in the Court's opinion ... that there is any danger that state law will conflict with federal policy").

182 Id. 486.

183597 F.2d 789 (2d Cir. 1979). See text accompanying notes 135 \& 136 supra. 
alleged that proxy statements used in connection with the election of the subject corporation's board of directors were false and misleading because they failed to disclose the circumstances surrounding modification of a stock option plan. In reversing the district court, ${ }^{184}$ the Second Circuit held that a reasonable shareholder could have considered the nondisclosed information important, and remanded the issue. ${ }^{185}$ Thereafter, the defendant directors established a special litigation committee composed of two newly appointed directors. The committee, after conducting an investigation, recommended that the derivative suit be terminated because it was not in the corporation's best interests. ${ }^{186}$ The defendants thereupon moved for summary judgment. Applying the test enunciated in Burks, the district court granted the motion. ${ }^{187}$ Following an Eighth Circuit decision, Abbey v. Control Data Corp., ${ }^{188}$ Judge Weinfeld stated that "under Delaware law a committee of disinterested directors, properly vested with the power of the board, may in the exercise of their business judgment require the termination of a derivative suit brought on the corporation's behalf." 189 Upon turning to Burks's second prong, the court held that the federal policies underlying section 14(a) would not be frustrated by termination of the derivative suit and that, accordingly, the suit should be dismissed. ${ }^{190}$ Several recent federal decisions have taken similar stances toward the business judgment rules of Delaware and other states, and have dismissed derivative suits on the basis of recommendations made by special litigation committees composed of disinterested directors. ${ }^{191}$

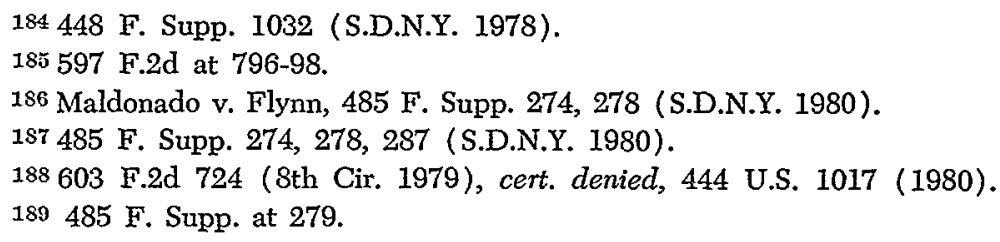

190 Id. 280-87. Answering both of Burks' prongs affirmatively, the court commented that "if a committee of independent, personally disinterested directors of Zapata has determined in good faith that in its business judgment the continuation of this action is not in the best interests of that corporation, the action must be dismissed." Id. 282. But see Galef v. Alexander, 615 F.2d 51, 60-62 (2d Cir. 1980) (dismissal of derivative suit improper where defendant directors who sought dismissal stood in a "dual relation" that prevented an unbiased exercise of judgment). 191 Lewis v. Anderson, 615 F.2d 778 (9th Cir. 1979), cert. denied, 101 S. Ct. 206 (1980) (California law); Abbey v. Control Data Corp., 603 F.2d 724 (8th Cir. 1979), cert. denied, 444 U.S. 1017 (1980) (Delaware law); Genzer v. Cunningham, 498 F. Supp. 682 (E.D. Mich. 1980) (Michigan law); Siegal v. Merrick, 84 F.R.D. 106 (S.D.N.Y. 1979) (dicta; Delaware law); Lewis v. Adams, No. 77-266C (N.D. Okla. Nov. 15, 1979) (Delaware law). See also Rosengarten v. Int'l Tel. \& Tel. Corp., 466 F. Supp. 817 (S.D.N.Y. 1979); Gall v. Exxon Corp., 418 F. Supp. 508 (S.D.N.Y. 1976). But see Galef v. Alexander, 615 F.2d 
Apparently, however, these federal interpretations of state business judgment rules underestimated the sensitivity of some state courts to investor interests. For example, the plaintiffs in Maldo. nado, in addition to their federal claims, brought suit in the Delaware Chancery Court on various state law claims. ${ }^{192}$ Defendants argued, as they did in federal court, that the business judgment rule required dismissal of the state law claims. ${ }^{193}$ Noting the spate of recent federal decisions allowing disinterested directors to terminate derivative suits, ${ }^{194}$ the Delaware chancellor stated:

All of these cited federal cases . . . incorrectly assume that State law necessarily enables the corporate directors (or a committee thereof) to compel the dismissal of a pending stockholder's derivative suit by invoking the business judgment rule. . . . It is clear, however, that under well settled Delaware law, the directors cannot compel the dismissal of a pending stockholder's derivative suit which seeks redress for an apparent breach of fiduciary duty, by merely reviewing the suit and making a business judgment that it is not in the best interests of the corporation. ${ }^{195}$

The court rejected the defendant's attempt to dismiss the suit. ${ }^{196}$ Currently on appeal to the Delaware Supreme Court, ${ }^{197}$ the chancery court's decision provides persuasive evidence that some state courts are displaying heightened concern for shareholder interests, ${ }^{198}$

51 (2d Cir. 1980) (Ohio law unclear); Abella v. Universal Leaf Tobacco, Inc., 495 F. Supp. 713 (E.D. Va. 1980) (dismissal improper under Virginia law); Maher v. Zapata Corp., 490 F. Supp. 348 (S.D. Tex. 1980) (dismissal improper under Delaware law).

192 Maldonado v. Flynn, 413 A.2d 1251 (Del. Ch. 1980), subsequently dismissed on res judicata grounds, 417 A.2d 378 (Del. Ch. 1980), appeal accepted, No. 113-1980 (Del. June 5, 1980) (argued Oct. 16, 1980).

193413 A.2d at $1255-56$.

194 Id. 1256-57 (citing Lewis v. Anderson, 615 F.2d 778 (9th Cir. 1979), cert. denied, 101 S. Ct. 206 (1980)); Abbey v. Control Data Corp., 603 F.2d 724 (8th Cir. 1979), cert. denied, 444 U.S. 1017 (1980); Lewis v. Adams, No. 77266C (N.D. Okla., Nov. 15, 1979); Siegal v. Merrick, 84 F.R.D. 106 (S.D.N.Y. 1979); Auerbach v. Bennett, 47 N.Y.2d 619, 393 N.E.2d 994, 419 N.Y.S.2d 920 (1979).

105 Maldonado, 413 A.2d at 1257.

190 Id. 1263.

197 See note 192 supra.

198 Two recent state court decisions in Texas rejected attempts by defendants to dismiss derivative actions on the basis of recommendations of the board of directors. Sonics Int'l, Inc. v. Dorchester Enter., Inc., 593 S.W.2d 390 (Tex. Civ. App. 1980); Zauber v. Murray Sav. Ass'n, 591 S.W.2d 932 (Tex. Civ. App. 1979). But see Auerbach v. Bennett, 47 N.Y.2d 619,393 N.E.2d 994, 419 N.Y.S.2d 920 (1979) (New York Court of Appeals recognized propriety of committee composed of disinterested directors to terminate shareholder derivative action against fellow directors; the court permitted inquiry only in regard to assessment of the 
and indeed, may be ahead of the federal courts in certain respects. ${ }^{199}$

The preceding discussion illustrates that the federal and state courts are engaged in a novel experiment in federalism. A theme underlying the Delaware cases, such as Singer and Maldonado,200 and the post-Santa $\mathrm{Fe}$ federal cases, is that of corporate accountability. Both the federal and state courts are becoming less tolerant of director self-dealing and conflicts of interest that inflict hardship on the investing public. ${ }^{201}$ The Goldberg line of cases, drawing both on the new approach of the Delaware courts and on the federal interest in full and fair disclosure, represents this school of thought. ${ }^{202}$ Viewed in this light, these cases, far from emasculating the state law of fiduciary duty, may well help form a desirable relationship among compatible federal and state interests.

This conclusion is supported by the curious relationship that has existed in the past between state and federal regulation of corporate malfeasance. As suggested above, state inaction in the field may have been due in part to perceptions that the federal government was primarily responsible for the protection of shareholders. ${ }^{203}$ Santa $F e$, and other decisions cutting back on the scope of the "federal corporation law," have brought into question the continued validity of such views. Consequently, there may well be new pressures on the states to provide for the protection of investors, as state courts and legislatures may no longer perceive the federal government as the primary source of regulation. This observation of the state-federal relationship in the corporate area is consistent with the recent movement toward increased state court sensitivity to shareholder interests and suggests that state protections for investors may continue to develop.

"independence" of committee's members and the appropriateness and adequacy of investigative procedures selected and pursued by committee).

199 It is interesting to note that subsequent to the Delaware Chancery Court's decision in Maldonado, two federal courts have applied that decision's rationale to preclude dismissal under the applicable state law. Abella v. Universal Leaf Tobacco Co., 495 F. Supp. 713 (E.D. Va. 1980) (Virginia law); Maher v. Zapata Corp., 490 F. Supp. 348 (S.D. Tex. 1980) (Delaware law). For further commentary on the subject, see Dent, The Power of Directors to Terminate Shareholder Litigation: The Death of the Derivative Suit?, 75 Nw. U. L. Rev. 96 (1980); Gammon, Derivative Suits, 12 Rev. SEc. REg. 887 (1979); Steinberg, The Use of Special Litigation Committees to Terminate Shareholder Derivative Suits, 35 U. MIAMI L. REv. 1 (1980); Note, The Business Judgment Rule in Derivative Suits Against Directors, 65 Connele L. Rev. 600 (1980).

200 See notes 77-90 supra \& accompanying text.

201 See, e.g., notes 77-90 \& 136 supra \& accompanying text.

202 See notes 98-126 supra \& accompanying text.

203 See notes $44-47$ supra \& accompanying text. 


\section{CONCLUSION}

One approach in analyzing recent federal and state court decisions in the rule $10 \mathrm{~b}-5$ and related corporate areas is from the perspective of federalism. These decisions may well underscore that the federal judiciary, particularly the Supreme Court, has become acutely aware that undue extension of the rule $10 \mathrm{~b}-5$ remedy into previously untouched areas may displace regulation that has traditionally been within the purview of the states. On the other hand, the Goldberg line of cases, particularly when viewed in conjunction with recent Delaware decisions, may well reflect a desirable accommodation between federal and state interests. The extent to which the federal and state courts may continue on this experimental path in federalism is not yet certain. Their journey, however, should receive the attention of all corporate practitioners and academicians. 